\title{
The Late Cretaceous
}

\section{Cephalopod Haresiceras}

Reeside and Its

Possible Origin

By WILLIAM A. COBBAN

SHORTER CONTRIBUTIONS TO GENERAL GEOLOGY

GEOLOGICAL SURVEY PROFESSIONAL PAPER 454-I

Haresiceras, which seems to have been derived from the scaphitid stock of ammonites, provides a means of correlating thin units of strata in the Western Interior region

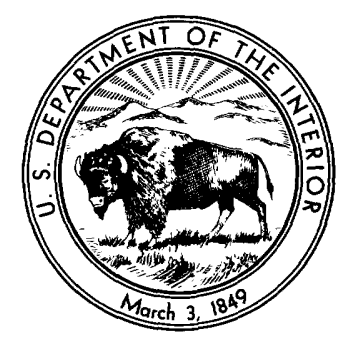




\section{UNITED STATES DEPARTMENT OF THE INTERIOR \\ STEWART L. UDALL, Secretary}

\section{GEOLOGICAL SURVEY}

Thomas B. Nolan, Director 


\section{CONTENTS}

Abstract

Introduction.

Gequen

Sweetgrass arch in northwestern Montana

Mosby area in east-central Montana ...........

Porcupine dome in east-central Montana . . . ......

Black Hills uplift in southeastern Montana and western South Dakota

Elk Basin area in southern Montana and northwestern Wyoming.

Hardin area in south-central Montana

\begin{tabular}{r|r} 
Page & Sequence of fossils-Continued \\
1 & Buffalo area in north-central Wyoming \\
1 & Salt Creek oil field in east-central Wyoming \\
1 & Wind River Basin in west-central Wyoming \\
4 & Green River area in east-central Utah \\
6 & Summary of faunal sequences \\
6 & Age of Haresiceras \\
6 & Origin of and evolution within Haresiceras \\
7 & Systematic descriptions \\
8 & Literature cited.
\end{tabular}

Page

I 9

9

9

10

10

11

11

13

18

21

\section{ILLUSTRATIONS}

[Plates follow index]

Plate 1. Desmoscaphites, Clioscaphites, Haresiceras, and Scaphites.

2. Haresiceras.

3. Haresiceras and Clioscaphites.

FIGURE 1. Index map
2-4. Stratigraphic relations-

2. Between northwestern Montana and the Black Hills

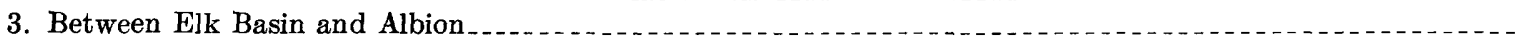

4. Between the Wind River Basin and Rawlins

5. Lineages of Clioscaphites, Desmoscaphites, and Haresiceras

6. Sutures of Clioscaphites, Desmoscaphites, and Haresiceras

7. Cross sections of Haresiceras placentiforme.

\section{TABLES}

TABLE 1. Localities at which fossils were collected

2. Possible correlation of the zones of Haresiceras to the late Santonian and early Campanian faunal zones in Europe 



\title{
THE LATE CRETAGEOUS GEPHALOPOD HARESICERAS REESIDE AND ITS POSSIBLE ORIGIN
}

\author{
By William A. Cobban
}

\begin{abstract}
The ammonite Haresiceras is known from 43 localities in the Western Interior of the conterminous United States. The genus is represented by at least four species, which are from oldest to youngest, Haresiceras mancosense (Reeside), H. montanaense (Reeside), H. placentiforme Reeside, and $H$. natronense Reeside. A fifth form, $\boldsymbol{H}$. fisheri Reeside, may be a variant of 'H. natronense. Haresiceras mancosense and $H$. montanaense are each represented by two forms, an early form and a late form.

The older species of Haresiceras are stouter than the younger species and have less complex sutures. These older species have constrictions on the early juvenile whorls, arched to nearly flat venters, and ribbing differentiated into primaries and secondaries on the adult body chamber; later species lack constrictions, possess flat to slightly concave venters, and have ribbing tending to be of uniform strength on the adult body chamber.

The earliest species, Haresiceras mancosense, which combines characters of Clioscaphites, Desmoscaphites, and Haresiceras, is assigned to a new subgenus Mancosiceras. Inasmuch as Haresiceras (Mancosiceras) mancosense is contemporaneous with Desmoscaphites but younger than Clioscaphites, it probably was derived from some species of Clioscaphites that trended toward compression of the whorls and flattening of the venter. Clioscaphites platygastrus bridges the gap well between the stouter and more round-ventered species of Clioscaphites and the more slender $H$. (M.) mancosense.
\end{abstract}

Haresiceras (Mancosiceras) mancosense is associated with Desmoscaphites, Uintacrinus, and Marsupites of late Santonian age. Haresiceres placentiforme, $H$. natronense, $H$. fisheri, and the late form of $H$. montanaense are found with Scaphites hippocrepis of early Campanian age. The early form of $H$. montanaense occurs in rocks older than those containing Scaphites hippocrepis and younger than those containing Desmoscaphites and free-swimming crinoids; a very early Campanian age seems to be the best choice.

\section{INTRODUCTION}

Haresiceras is a rare ammonite known only from the Western Interior of the conterminous United States. This genus, named for C. J. Hares, was established by Reeside (1927a, p. 17) to include small ammonites that have compressed whorls, very narrow umbilicus, flat venter bordered by small ventrolateral nodes, weak sigmoidal ribs that cross the venter with a forward arching, and sutures characterized by a long triangular first lateral lobe. Three species were de- scribed, $H$. placentiforme (genotype), $H$. natronense, and $H$. fisheri. Reeside, with some reservations, assigned Haresiceras to the subfamily Hoplitinae of the family Cosmoceratidae [Kosmoceratidae] Haug. In addition to these species of Haresiceras, Reeside (1927a, p. 15, 20) described two other ammonites, which he named Puzosia (Latidorsella) mancosensis and Acanthoceras? montanaense. These two ammonites are included in the present treatment because the writer believes they are early forms of Haresiceras.

Since the publication of Reeside's important paper, new collections of fossils that include his species have been made from carefully measured stratigraphic sections by geologists of the U.S. Geological Survey and of oil companies. These collections have shed considerable light on the age relations of the various species of Haresiceras and on the possible origin of the genus. The present investigation was prompted by a need for close zoning of strata adjoining the boundary of the Colorado and Montana Groups. The presence of Haresiceras in rocks assigned to the Colorado Group as well as in rocks assigned to the Montana Group has been pointed out previously (Cobban and others, 1962).

The figured specimens are in the U.S. National $\mathrm{Mu}-$ seum, Washington, D.C. R. E. Burkholder, of the Geological Survey, photographed the fossils.

\section{GEOGRAPHIC DISTRIBUTION}

Haresiceras is known from 43 localities in the Western Interior. The general position of each locality is shown in figure 1. Detailed data concerning the localities, stratigraphic position, and collectors are given in table 1 .

\section{SEQUENCE OF FOSSILS}

Reeside recognized as long ago as 1924 (p. 11, 12, pl. 3) a Telegraph Creek fauna and a younger Eagle fauna named for the two oldest formations of the Montana Group. Later, Desmoscaphites bassleri Reeside was designated the guide fossil for the Telegraph Creek fauna and Scaphites hippocrepis (DeKay) the index 

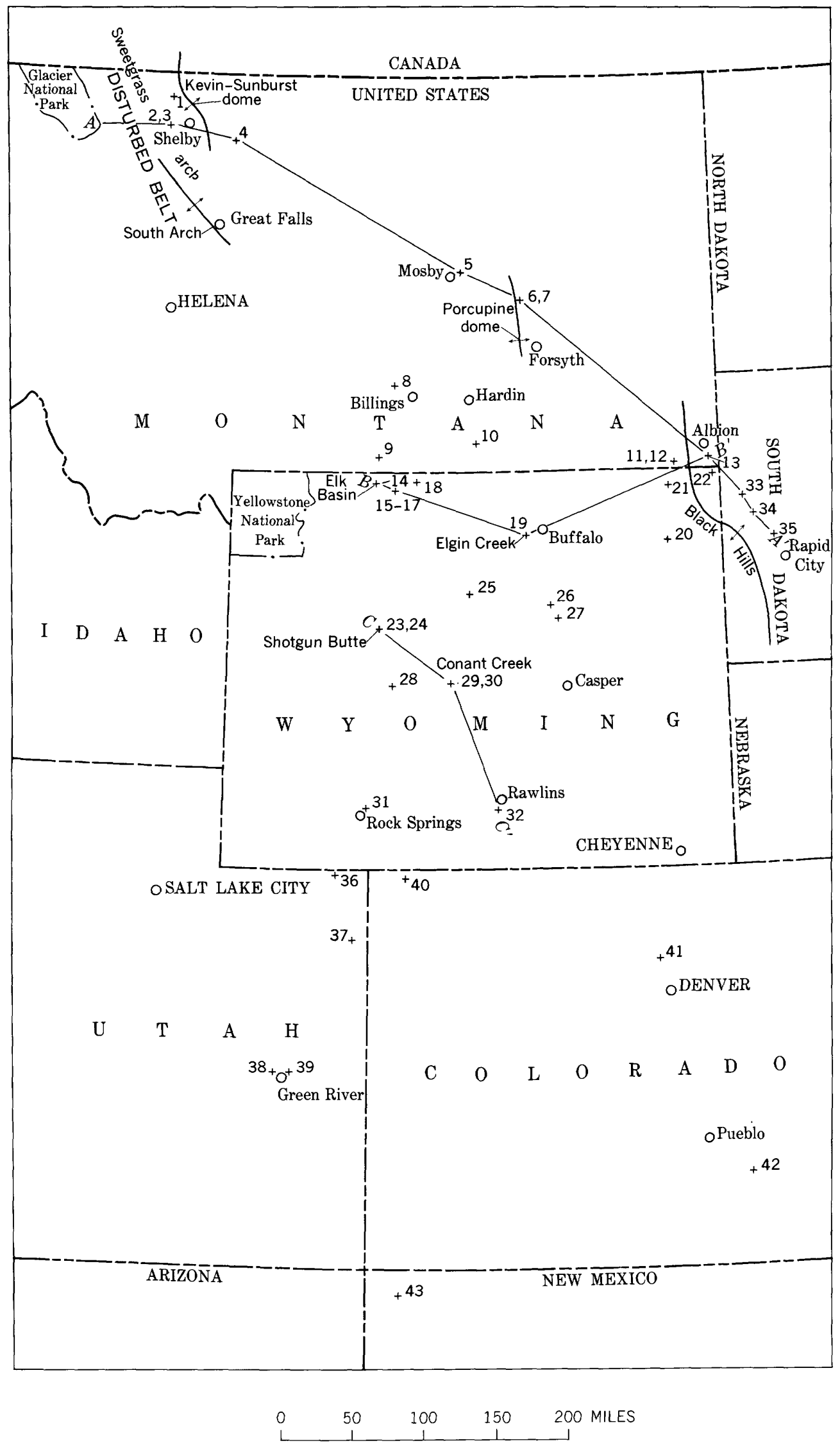

Figure 1.- Index map showing Haresiceras localities and the lines of sections of figures 2-4. Numbers refer to the detailed description of localities in table 1. 
TABLE 1.-Localities at which fossils were collected

\begin{tabular}{|c|c|c|}
\hline $\begin{array}{l}\text { Locality } \\
\text { on figure } \\
1\end{array}$ & $\begin{array}{l}\text { U.S. Geo- } \\
\text { logical } \\
\text { Survey } \\
\text { Mesozoic } \\
\text { locality }\end{array}$ & $\begin{array}{c}\text { Collector and year of collection, description of locality, } \\
\text { and stratigraphic assignment }\end{array}$ \\
\hline 1. & 11995 & $\begin{array}{l}\text { A. J. Collier, } 1923 . \text { Three miles northwest } \\
\text { of Kevin, in sec. 17, T. } 35 \text { N., R. 3 W., } \\
\text { Toole County, Mont. Marias River } \\
\text { Shale, } 20 \mathrm{ft} \text { below top. }\end{array}$ \\
\hline $2 \ldots$ & 21420 & $\begin{array}{l}\text { W. A. Cobban, } 1948 \text {. Eight miles west of } \\
\text { Shelby, in the NE1/4 sec. 31, T. 32 N., } \\
\text { R. } 3 \text { W., Toole County, Mont. Telegraph } \\
\text { Creek Formation, } 24-35 \mathrm{ft} \text { above base. }\end{array}$ \\
\hline $3 \ldots$ & D696 & $\begin{array}{l}\text { W. L. Rohrer, } 1955 \text {. S1/2SW1/4 } \mathrm{N}^{1} / 4 \text { sec. } \\
31 \text {, T. } 32 \mathrm{~N} \text {., R. 3 W., Toole County, } \\
\text { Mont. Telegraph Creek Formation, } 148 \\
\text { ft above base. }\end{array}$ \\
\hline 4 & 20774 & $\begin{array}{l}\text { G. W. Beer, } 1946 . \quad \text { Sec. } 19, \text { T. } 30 \text { N., R. R. } \\
5 \text { E., Liberty County, Mont. Telegraph } \\
\text { Creek Formation, } 49 \mathrm{ft} \text { above base. }\end{array}$ \\
\hline 5 & 21405 & $\begin{array}{l}\text { W. A. Cobban, } 1948 \text {. About } 3.4 \text { miles east } \\
\text { of Mosby, in the SW } 1 / 4 \mathrm{NE} 1 / 4 \mathrm{SE} 1 / 4 \text { sec. } 5 \text {, T. } \\
14 \mathrm{~N} . \mathrm{R} \text {. } 31 \mathrm{E} \text {., Garfield County, Mont. } \\
\text { Gammon Shale, } 45 \mathrm{ft} \text { above base. }\end{array}$ \\
\hline 6. & D3519 & $\begin{array}{l}\text { J. R. Gill, 1961. Thirty-six miles west- } \\
\text { northwest of Forsyth in the NW1/4NW1/4 } \\
\text { sec. 36, T. 12 N., R. 38 E., Rosebud } \\
\text { County, Mont. Gammon Shale, from at } \\
\text { least } 125 \mathrm{ft} \text { above base. }\end{array}$ \\
\hline $7 \ldots$ & D3520 & $\begin{array}{l}\text { W. A. Cobban, } 1948 \text {. Thirty-seven miles } \\
\text { west-northwest of Forsyth in the SE1/4 } \\
\text { sec. 27, T. 12 N., R. 38 E., Rosebud } \\
\text { County, Mont. From lower part of } \\
\text { Gammon Shale. }\end{array}$ \\
\hline 8. & 11208 & $\begin{array}{l}\text { W. T. Thom, Jr. } 1922 \text {. SW } 1 / 4 \text { sec. } 26, \text { T. } 1 \\
\text { S., R. } 27 \text { E., Yellowstone County, Mont. } \\
\text { Telegraph Creek Formation }\end{array}$ \\
\hline 9 & 9649 & $\begin{array}{l}\text { C. J. Hares, } 1916 \text {. Sec. 27, T. } 7 \text { S., R. R. } \\
23 \text { E., Carbon County, Mont. From } 150 \\
\text { ft below Elk Basin Sandstone Member of } \\
\text { Telegraph Creek Formation. }\end{array}$ \\
\hline 10 & 10752 & $\begin{array}{l}\text { T. W. Stanton and W. T. Thom, Jr., } 1921 . \\
\text { Between Shoulderblade Butte and St. } \\
\text { Xavier Mesa, near the south quarter } \\
\text { corner sec. 27, T. } 4 \text { S., R. } 33 \text { E., Big Horn } \\
\text { County, Mont. Near base of Telegraph } \\
\text { Creek Formation. }\end{array}$ \\
\hline 11 & 12631 & $\begin{array}{l}\text { W. W. Rubey, } 1924 \text {. Sec. 1, T. } 9 \text { S., R. } 56 \\
\text { E., Carter County, Mont. From Gam- } \\
\text { mon Ferruginous Member of Pierre Shale, } \\
20 \mathrm{ft} \text { below Groat Sandstone Bed. }\end{array}$ \\
\hline 12 & 12639 & $\begin{array}{l}\text { W. W. Rubey, } 1924 . \quad \text { S3/2 sec. } 12 . \text { T. } 8 \text { S., } \\
\text { R. } 56 \text { E., Carter County, Mont. Gammon } \\
\text { Ferruginous Member of Pierre Shale, } \\
\text { about } 400 \mathrm{ft} \text { below Groat Sandstone Bed. }\end{array}$ \\
\hline 13 & 23477 & $\begin{array}{l}\text { W. A. Cobban, 1941. Head of Owl Creek } \\
\text { in the NE1/4 NE1/4 sec. 13, T. 9 S., R. } 61 \\
\text { E., Carter County, Mont. From gray } \\
\text { limestone concretions in Gammon Ferru- } \\
\text { ginous Member of Pierre Shale, about } 130 \\
\text { ft below base of Groat Sandstone Bed. }\end{array}$ \\
\hline 14. & 9625 & $\begin{array}{l}\text { C. J. Hares, } 1916 \text {. Southwest side of Elk } \\
\text { Basin in the NE } 1 / 4 \text { sec. } 25 \text {, T. } 58 \text { N., R. } \\
100 \text { W., Park County, Wyo. Elk Basin } \\
\text { Sandstone Member of Telegraph Creek } \\
\text { Formation. }\end{array}$ \\
\hline 15. & 9672 & $\begin{array}{l}\text { C. J. Hares, 1916. Twelve miles west of } \\
\text { Lovell, in the E1/2 T. } 56 \text { N., R. 98 W., } \\
\text { Park County, Wyo. From Elk Basin } \\
\text { Sandstone Member of Telegraph Creek } \\
\text { Formation. }\end{array}$ \\
\hline 16 & 17645 & $\begin{array}{l}\text { D. A. Andrews, } 1936 \text {. About } 3 \text { miles south- } \\
\text { west of Frannie in the SE1/4 sec. 10, T. } 57 \\
\text { N., R. } 98 \text { W., Park County, Wyo. Basal } \\
\text { part of Telegraph Creek Formation. }\end{array}$ \\
\hline
\end{tabular}

TABLE 1.-Localities $a^{\prime}$ which fossils were collected-Continued

\begin{tabular}{|c|c|c|}
\hline $\begin{array}{c}\text { Locality } \\
\text { on figure } \\
1\end{array}$ & $\begin{array}{l}\text { U.S. Geo- } \\
\text { logical } \\
\text { Survey } \\
\text { Mesozoic } \\
\text { locality }\end{array}$ & $\begin{array}{l}\text { Colleetor and year of collection, description of locality, } \\
\text { and stratigraphic assignment }\end{array}$ \\
\hline.- & 21851 & $\begin{array}{l}\text { J. B. Reeside, Jr., and D. A. Andrews, } 1938 . \\
\text { Sec. 16, T. } 57 \text { N., R. } 98 \text { W., Park County, } \\
\text { Wyo. From just below Elk Basin Sand- } \\
\text { stone Member of Telegraph Creek Forma- } \\
\text { tion. }\end{array}$ \\
\hline $18 \ldots$ & 9740 & $\begin{array}{l}\text { C. J. Hares, } 1916 \text {. Six miles northwest of } \\
\text { Lovell, north of Shoshone River, in T. } \\
57 \text { N., R. 95 W., Big Horn County, Wyo. } \\
\text { Elk Basin Sandstone Member of Telegraph } \\
\text { Creek Formation. }\end{array}$ \\
\hline 19 & 22822 & $\begin{array}{l}\text { R. K. Hose and W. J. Mapel, } 1950 . \text { North } \\
\text { of Elgin Creek in the NE1/4 NW1/4 sec. } 13 \text {, } \\
\text { T. } 49 \text { N., R. } 83 \text { W., Johnson County, Wyo. } \\
\text { Cody Shale, from limestone concretions } \\
748 \text { ft below Shannon Sandstone Member. } \\
\text { W. W. Rubey, 1924. SE } 1 / 4 \text { sec. } 32 \text {, T. } 49 \text { N., }\end{array}$ \\
\hline & & $\begin{array}{l}\text { W. W. Rubey, } 66 \text { W., Crook County, Wyo. From } \\
\text { R. } 66 \text { Wouge } \\
175 \mathrm{ft} \text { above base of Gammon Ferruginous } \\
\text { Member of Pierre Shale. }\end{array}$ \\
\hline
\end{tabular}

W. W. Rubey, 1923. North of Mud Creek, in the NW1/4 sec. 30 , T. 56 N., R. $67 \mathrm{~W}$. Crook County, Wyc. From limestone concretions in Gammon Ferruginous Member of Pierre Shale.

W. W Rubey, 1924. Sec. 26, T. 58 N., R. 61 W., Crook, County, Wyo. From 120 ft above base of Gammon Ferruginous Member of Pierre Shale.

$23 \ldots \ldots 23110 \quad$ J. B. Reeside, Jr., and others, 1950. East Sheep Creek in the NW $1 / 4 \mathrm{SE}^{1} / 4 \mathrm{NE}^{1 / 4}$ sec. 23, T. 6 N., R. 2 E., Fremont County, Wyo. Cody Shale, from about $1,275 \mathrm{ft}$ below top.

24_._. 23112 M. L. Troyer, W. R. Keefer, and R. Burnside, 1950. East Sheep Creek in the E1\%NE1/4SE1/4 sec. 23 , T. 6 N., R. 2 E., Fremont County, Wyo. Cody Shale, from $550 \mathrm{ft}$ below top.

C. T. Lupton, 1915. Five miles southwest of junction of Buffalo and Nowood Creeks in T. 44 N., R. 88 W., Washakie County, Wyo. Cody Shale, from $250 \mathrm{ft}$ below top.

$26 \ldots$

J. B. Reeside, Jr., and others, 1950 . Along road to West Sussex oil field about 10 miles southeast of Kaycee, Johnson County, Wyo. Cody Shale (Steele Shale of former usage)

$27 \ldots 10701 \quad$ J. B. Reeside, Jr., 1921. Half a mile west of Castle Rock in Salt Creek oil field, Natrona County, Wyo. Cody Shale (Steele Shale of former usage), $200 \mathrm{ft}$ below Shannon Sandstone Member.

$28 \ldots$

J. B. Reeside, Jr., and others, $1949 . \quad$ NW 14 SW $1 / 4$ sec. 4, T. 33 N., R. 98 W., Fremont County, Wyo. Cody Shale, about 1,035 ft below top.

29

G. N. Pipiringos and K. A. Yenne, 1949. E1/2NW1/4SE1/4 sec. 7, T. 33 N., R. 93 W., Fremont County, Wyo. Cody Shale, about $1,060 \mathrm{ft}$ below top.

$30 \ldots$

R. A. MacDiarmid and P. E. Soister, 1956. Center of the $\mathrm{N}^{1 / 2} \mathrm{~N} 1 / 2 \mathrm{~N} 1 / 2$ sec. 19, $\mathrm{T}$. 33 N., R. 91 W., Fremont County, Wyo. Cody Shale, upper part.

$31 \ldots \ldots 22102$

L. A. Hale, 1950. Six miles northeast of Rock Springs, in sec. 14, T. 19 N., R. 104 W., Sweetwater County, Wyo. Baxter Shale, from $785 \mathrm{ft}$ below top. 
TABLE 1.-Localities at which fossils were collected-Continued

\begin{tabular}{|c|c|c|}
\hline $\begin{array}{c}\text { Locality } \\
\text { on figure } \\
1\end{array}$ & $\begin{array}{l}\text { U.S. Geo- } \\
\text { logical } \\
\text { Survey } \\
\text { Mesozoic } \\
\text { locality }\end{array}$ & $\begin{array}{c}\text { Collector and year of collection, description of locality, } \\
\text { and stratigraphic assignment }\end{array}$ \\
\hline $32 \ldots$ & D3053 & $\begin{array}{l}\text { J. H. Smith, } 1961 \text {. About } 10 \text { miles south } \\
\text { of Rawlins, in the NW } 14 \text { sec. } 14, \mathrm{~T} .19 \\
\text { N., R. } 88 \text { W., Carbon County, Wyo. } \\
\text { Steele Shale, from } 1,468 \mathrm{ft} \text { above base. }\end{array}$ \\
\hline 33. & 12654 & $\begin{array}{l}\text { W. W. Rubey, } 1924 \text { W W1/2 sec. 11, T. } 8 \text { N., } \\
\text { R. } 5 \text { E., Butte County, S. Dak. From } \\
50 \text { ft above base of Gammon Ferruginous } \\
\text { Member of Pierre Shale. }\end{array}$ \\
\hline $34 \ldots$ & D1847 & $\begin{array}{l}\text { J. R. Gill, 1958. Three miles north of } \\
\text { Bear Butte, in the NE1/4NE1/4 sec. } 6, \mathrm{~T} .6 \\
\text { N., R. } 6 \text { E., Meade County, S. Dak. } \\
\text { From lens of marlstone in lower part of } \\
\text { Gammon Ferruginous Member of Pierre } \\
\text { Shale. }\end{array}$ \\
\hline $35_{-}$ & D1849 & $\begin{array}{l}\text { J. R. Gill, 1958. About } 3.5 \text { miles south of } \\
\text { Alkali Creek, in the NW1/4 sec. 9, T. } 4 \\
\text { N., R. } 8 \text { E., Meade County, S. Dak. } \\
\text { From lens of marlstone } 50 \mathrm{ft} \text { above base } \\
\text { of Gammon Ferruginous Member of } \\
\text { Pierre Shale. }\end{array}$ \\
\hline 36. & D3420 & $\begin{array}{l}\text { A. D. Zapp and W. A. Cobban, } 1961 . \\
\text { SW1/4SW1/4NE1/4 sec. 22, T. } 3 \text { N., R. } 21 \text { E., } \\
\text { Daggett County, Utah. Baxter Shale, } \\
\text { from thin-bedded sandstone bed in upper } \\
\text { part. }\end{array}$ \\
\hline 37 & 23255 & $\begin{array}{l}\text { W. A. Cobban, 1945. About } 6.5 \text { miles } \\
\text { southeast of Jensen, in the S } 1 / 2 \text { sec. } 12 \text {, } \\
\text { T. } 6 \text { S., R. } 23 \text { E., Uintah County, Utah. } \\
\text { Mancos Shale, from thin lens of sandstone } \\
2,645 \mathrm{ft} \text { above base. }\end{array}$ \\
\hline 38. & 13247 & $\begin{array}{l}\text { E. M. Spieker and J. B. Reeside, Jr., } 1925 \text {. } \\
\text { One mile east of Desert, in the SEi/4 T.20 } \\
\text { S., R. } 14 \text { E., Emery County, Utah. } \\
\text { Mancos Shale, from concretion } 1,710 \mathrm{ft} \\
\text { above base. }\end{array}$ \\
\hline $39 \ldots$ & 13340 & $\begin{array}{l}\text { D. J. Fisher, } 1925 \text {. NW1/4 sec. 18, T. } 21 \mathrm{~S} \text {, } \\
\text { R. } 18 \text { E., Emery County, Utah. Mancos } \\
\text { Shale, from } 800 \mathrm{ft} \text { below top. }\end{array}$ \\
\hline $40 \ldots \ldots$ & 11948 & $\begin{array}{l}\text { J. B. Reeside, Jr., J. D. Sears, and W. H. } \\
\text { Bradley, 1923. Near Vermilion Creek, in } \\
\text { the NE1/4 T. } 10 \text { N., R. } 101 \text { W., Moffat } \\
\text { County, Colo. Mancos Shale, from } 1,439 \\
\text { ft below top. }\end{array}$ \\
\hline 41 & D2827 & $\begin{array}{l}\text { G. R. Scot, } 1960 . \text { Four miles north of } \\
\text { Boulder, in the } \mathrm{SW} 1 / 4 \mathrm{SE} 1 / 4 \mathrm{sec} 1 \text {, T. } 1 \mathrm{~N} \text {,, } \\
\text { R. } 71 \text { W., Boulder County, Colo. } \\
\text { Niobrara Formation, from chalky lime- } \\
\text { stone } 28 \mathrm{ft} \text { below top. }\end{array}$ \\
\hline 42 & D3266 & $\begin{array}{l}\text { G. R. Scott and W. A. Cobban, } 1961 \text {. One } \\
\text { mile east of Apishapa River, in the } \\
\text { NE1/4SW1/4NW14 sec. } 23 \text {, T. } 23 \text { S., R. } 59 \\
\text { W., Otero County, Colo. Niobrara For- } \\
\text { mation, from chalky limestone } 84 \mathrm{ft} \text { below } \\
\text { top. }\end{array}$ \\
\hline 43 & 10142 & $\begin{array}{l}\text { Harvey Bassler, } 1917 \text {. West foot of Hog- } \\
\text { back Mountain, in sec. } 32 \text {, T. } 30 \text { N., R. } \\
16 \text { W., San Juan County, N. Mex. Man- } \\
\text { cos Shale, from } 160 \mathrm{ft} \text { below top. }\end{array}$ \\
\hline
\end{tabular}

fossil for the Eagle fauna (Reeside, 1944). In terms of the standard stages of the Upper Cretaceous Desmoscaphites bassleri was assigned to the upper part of the Santonian and Scaphites hippocrepis was placed in the lower part of the Campanian (Reeside, 1927b, p. 28, $30 ; 1944)$. This usage of D. bassleri and S. hippocrepis as zonal indices has continued to the present time.
Haresiceras, as defined by Reeside, has been placed in the Scaphites hippocrepis Range Zone and assigned an early Campanian age (Cobban and Reeside, 195\%, p. 1019). Reeside's Puzosia (Latidorsella) mancosensis was placed originally in the Eagle fauna (Reeside, 1924, p. 12, pl. 3) but later its presence with Desmoscaphites bassleri was noted (Thom and others, 1935, p. 54-56). Reeside's Acanthoceras? montanaense has been recorded only from below the Telegraph Creek Formation at one locality (Reeside, 1927a, loc. 9649 on distribution table).

Collections of fossils made subsequent to the publication of Reeside's monograph on the cephalopods of the Eagle Sandstone and related formations (1927a) revealed the possibility of recognizing subzones within Reeside's zones of Desmoscaphites bassleri and $S c a-$ phites hippocrepis. This refinement in zoning can be demonstrated best by considering the stratigraphic sections and fossil content in the following areas: (1) Sweetgrass arch in northwestern Montana, (2) vicinity of Mosby Post Office in east-central Montana, (3) Porcupine dome farther east in east-central Montana, (4) Elk Basin oil field and surrounding area in southern Montana and northwestern Wyoming, (5) Hardin area in south-central Montana, (6) Buffalo area in northcentral Wyoming, (7) Salt Creek oil field in east-central Wyoming, (8) Wind River Basin in west-central Wyoming, and (9) Green River area in east-central Utah.

\section{SWEETGRASS ARCH IN NORTHWESTERN MONTANA}

The Sweetgrass arch (fig. 1) consists of a northern structural feature, the Kevin-Sunburst dome, and a southern feature, the South arch (Dobbin and Erdmann, 1955). High on the west flank of the Sweetgrass arch, rocks ranging in age from middle Santonian to early Campanian consist of the following units from oldest to youngest: Marias River Shale, Telegraph Creek Formation, Virgelle Sandstone, and lower part of the nonmarine Two Medicine Formation (Cobban, 1955, p. 111-116).

Limestone concretions in the Marias River Shale contain many well-preserved fossils. The upper part of the formation, Kevin Shale Member, contains at least seven faunal zones of which only the upper three need be considered here (Cobban, 1951a, p. 2197). The oldest of these three is the Clioscaphites vermiformis Range Zone, which contains Inoceramus cordiformis Sowerby dating it as early middle Santonian (Seitz, 1956, p. 3, 4). This is succeeded by the Clioscaphites choteauensis Range Zone of probable late middle Santonian age. The uppermost part of the Kevin Shale Member is characterized by the Desmoscaphites erdmanni Range Zone, which has the lowest occurrence of 
Inoceramus patootensis de Loriol, Baculites thomi Reeside. Scaphites leei Reeside, and the free-swimming crinoid Uintacrinus socialis Grinnell. This zone can be assigned to the early part of the late Santonian (Cobban, 1962 , p. D140). In addition to these fossils, Collier $(1929$, p. 72 , loc. 11995$)$ collected a septate coil of an ammorite (pl. 1, figs. 25, 26) identified by Reeside as Puzosia (Schlueteria) n. sp. from a limestone concretion " *** 20 feet below the top of the Colorado Shale." The writer believes this specimen is a variant of the species described by Reeside as Puzosia (Latidorsella) mancosensis. Reeside's species is herein assigned to Haresiceras owing to the similarity of the suture pattern, the type of ribbing, and the flattened venter on the adult whorl to those of other species of Haresiceras.

The Telegraph Creek Formation contains Inoceramus patootensis, Baculites haresi Reeside, Desmoscaphites bassleri Reeside, Scaphites leei, and a late form of Haresiceras mancosense (fig. 1, locs. 2,3). The Inoceramus patootensis and Scaphites leei were originally listed as Inoceramus lundbreckensis McLearn and Scaphites cf. S. hippocrepis (Cobban, 1950, p. 1900). The specimens recorded as Puzosia (Latidorsella) mancosensis Reeside differ from Reeside's types by having a flattened venter at an earlier diameter and are thus transitional to Reeside's Acanthoceras? montanaense. The Sweetgrass arch specimens may deserve separate species rank, but until larger collections of this form permit an evaluation of the amount of variation, the specimens at hand are treated as a late form of Reeside's species. They are assigned to Haresiceras and placed in a new subgenus Mancosiceras.

Fossils have not been found in the Virgelle Sandstone on the east and west flanks of the Kevin-Sunburst dome which forms the northern part of the Sweetgrass arch in the Shelby area (fig. 1). West of Great Falls on the west flank of the South arch (fig. 1) and farther west, in the Disturbed belt near the east margin of the Rocky Mountain front, the Virgelle Sandstone is moderately fossiliferous and contains Inoceramus patootensis, Baculites haresi, and Desmoscaphites bassleri. The Virgelle Sandstone in these western areas is interpreted as the time equivalent of the Telegraph Creek Formation farther east and higher up on the Sweetgrass arch (fig. 2). Likewise, the upper part of the Marias River Shale is older west of the Sweetgrass arch than it is high up on the arch. In the Disturbed belt southwest of the Sweetgrass arch, thin-bedded sandstone and siltstone of Telegraph Creek lithology contain Clioscaphites vermiformis.

In summary, the ammonite sequence for the middle and late Santonian rocks on the Sweetgrass arch consists of the following, from oldest to youngest, (1) Clioscaphites vermiformis; (2) C. choteauensis; (3) Desmoscaphites erdmanni, Baculites thomi, and the early form of Haresiceras (Mancosiceras) mancosense; and (4) Desmoscaphites bassleri, Baculites haresi, and the late form of H. (M.) mancosense. Scaphites leei and Inoceramus patootensis are present in both Desmoscaphites zones (3 and 4) and a free-swimming crinoid, Uintacrinus socialis, is known from the older zone (3).

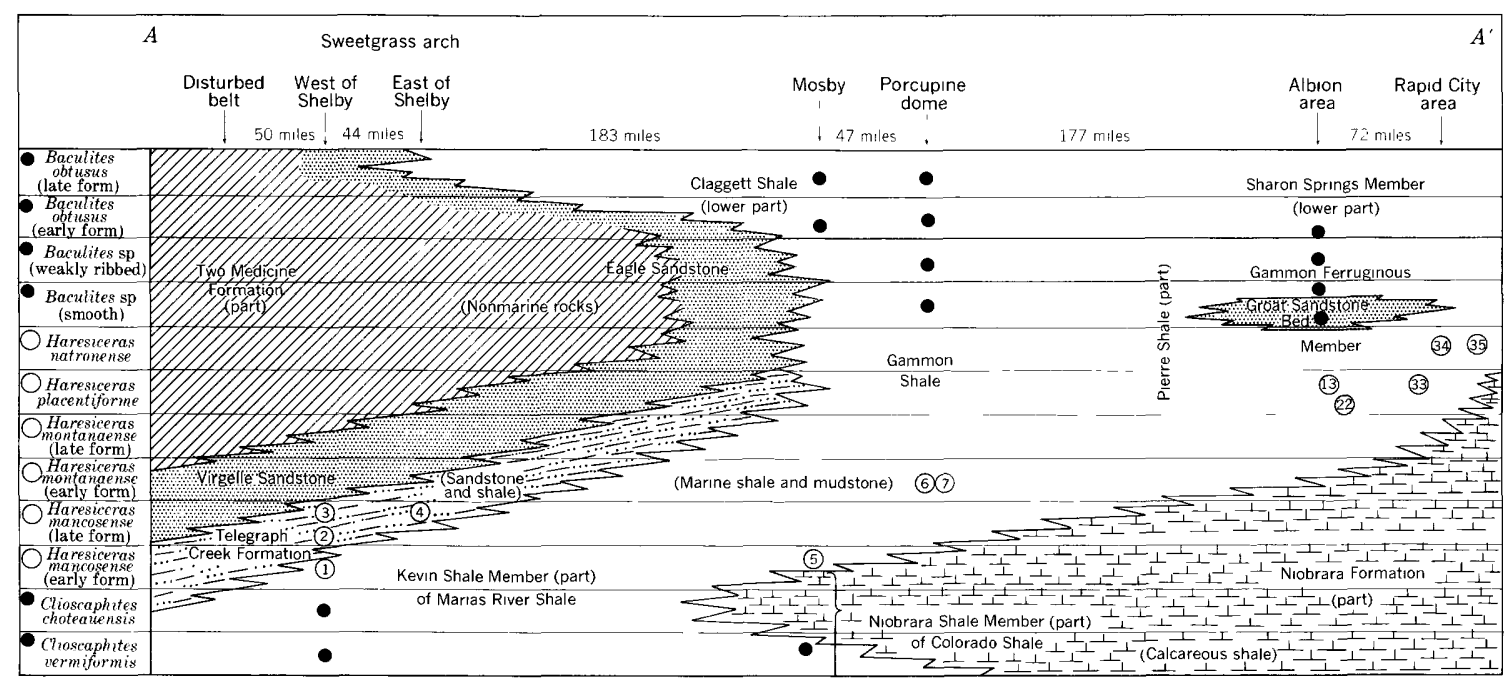

FIgURe 2.- Stratigraphic relations between the Disturbed belt in northwestern Montana and the east flank of the Black Hills uplift near Rapid City, S. Dak. Occurrences of Haresieeras are shown by circles enclosing their map locality numbers. Occurrences of guide fossils a little older or a little younger than Haresiceras that aided in constructing this cross section are indicated by large black dots. 


\section{MOSBY AREA IN EAST-CENTRAT MONTANA}

West of the Musselshell River in east-central Montana, rocks equivalent to the Marias River Shale are included in the upper part of the Colorado Shale. Here the Colorado Shale is overlain by thin-bedded sandstone, siltstone, and shale of the Telegraph Creek Formation and this in turn by the Eagle Sandstone. The Telegraph Creek Formation and Eagle Sandstone grade eastward into finer grained rocks, and the upper part of the underlying Colorado Shale becomes calcareous (fig. 2). East of the Musselshell River, in the vicinity of Mosby Post Office, the Telegraph Creek and Eagle are no longer identifiable but represented by a gray shale and mudstone unit that is in part sandy and contains beds of ferruginous concretions. This unit, resting on the yellow- and orange-weathering Niobrara Shale Member of the Colorado Shale and underlying the dark-gray Claggett Shale, represents the northwestward extension of the Gammon Ferruginous Member of the Pierre Shale of the Black Hills region. In the Mosby area and eastward beyond Porcupine dome, this ferruginous unit is a distinct formation to which the name Gammon Shale is applicable.

Near Mosby Post Office the Niobrara Member of the Colorado Shale consists of a lower noncalcareous shale unit that contains Clioscaphites vermiformis in its upper part and an upper and much thicker calcareous shale unit that has yielded, 50 feet below the top, Baculites thomi, Scaphites leei, Desmoscaphites sp., and small fragments of an Inoceramus that is probably $I$. patootensis. This collection may be from the Desmoscaphites erdmanni Range Zone. Limestone concretions 45 feet above the top of the Colorado Shale contain the round-ventered or early form of Haresiceras (Mancosiceras) mancosense associated with Baculites haresi and Scaphites leei (fig. 1, loc. 5). The Haresiceras and scaphite were originally recorded as $H$. natronense, $H$. placentiforme var. parvum, and Scaphites hippocrepis (Cobban, 1953, p. 100). Higher in the Gammon Shale, about 150 feet above the base, limestone concretions contain Inoceramus patootensis, Baculites aquilaensis Reeside, and Scaphites hippocrepis (DeKay) var. tenuis Reeside. Haresiceras and Scaphites were not observed higher in the Gammon; the upper part contains baculites that have weak flank ribs. The dark-gray Claggett Shale, which overlies the lighter colored Gammon Shale, contains numerous beds of bentonite in the lower part. A weakly sculptured form of Baculites obtusus Meek is in the basal part, and a more strongly sculptured form (the typical late form) of B. obtusus is found a little higher in this bentonitic unit.

In summary, the known faunal sequence in the Mosby area is, from oldest to youngest, (1) Clioscaphites vermiformis; (2) Desmoscaphites sp., Baculites thomi, and Scaphites leci; (3) Haresiceras (Mancosiceras) mancosense, Baculites haresi, and Scaphites leei; (4) Scaphites hippocrepis var. tenuis and Baculites aquilaensis; (5) baculites with weak flank ribs; (6) an early form of Baculites obtusus; and (7) a late form of $B$. obtusus. Inoceramus patootensis seems to have a range of from the second (2) to the fourth (4) of these zones.

\section{PORCUPINE DOME IN EAST-CENTRAL MONTANA}

North of Forsyth on the north flank of Porcupine dome (fig. 1), about 55 miles east-southeast of the Mosby locality, Reeside's Acanthoceras? montanaense, here assigned to Haresiceras. is found in limestone concretions at least 125 feet above the base of the Gammon Shale (fig. 1, locs. 6, 7). Associated fossils include Baculites haresi and Scaphites leei. Collections made higher in the Gammon by J. R. Gill, of the Geological Survey, reveal the presence of dominantly smooth baculites about 85 feet below the top of the formation and baculites that have weak flank ribs about 40 feet below the top. The lower 55 feet of the overlying Claggett Shale is characterized by numerous beds of bentonite. The weakly sculptured form of Baculites obtusus is present in the basal part of this bentonitic unit, whereas the more strongly sculptured form (the typical form) of this species is found higher in the unit.

\section{BLACK HILLS UPLIFT IN SOUTHEASTERN MONTANA AND WESTERN SOUTH DAKOTA}

Along the northeast flank of the Black Hills uplift, rocks of Santonian and Campanian age are represented by the Niobrara Formation and the overlying Pierre Shale. The lower part of the Pierre Shale consists of the Gammon Ferruginous Member and the younger Sharon Springs Member. About 10 miles southeast of Albion, near the common corner of Montana, South Dakota, and Wyoming (fig. 1), the Gammon attains a thickness of 785 feet. Here it is divided by the 45foot Groat Sandstone Bed (fig. 2) into a lower part 580 feet thick and an upper part 160 feet thick. Haresiceras placentiforme was found in limestone concretions 130 feet below the base of the Groat Sandstone Bed (fig. 1, loc. 13). Associated fossils include numerous specimens of Baculites aquitaensis and a single example of Scaphites aquisgranensis Schlüter $[=S$. aquilaensis Reeside]. Higher in the Gammon, about 75 feet below the Groat Sandstone Bed, a specimen of the fine-ribbed form of $S$. hippocrepis was found with smooth or nearly smooth adult baculites. Smooth adult baculites characterize the Groat Sandstone Bed and the lower part of the overlying Gammon. The juveniles of these baculites as well as the juveniles of the baculites 
75 feet below the Groat have widely spaced broad lateral nodes. Scaphites from the Groat are small flatventered undescribed forms entirely different from the slightly older $S$. hippocrepis. The uppermost 85 feet of the Gammon is charaterized by baculites that have weak lateral ribs on the adults.

The lower part of the Sharon Springs Member contains many layers of bentonite. A weakly sculptured form of Baculites obtusus is present in the basal part of this bentonitic sequence.

Haresiceras natronense has been found at two localities 50-70 miles southeast of Albion (fig. 1 locs. 34, 35). Associated fossils include a fine-ribbed form of Scaphites hippocrepis and smooth or nearly smooth baculites.
The fossils were found in lengthy lenses of marlstone, 50 feet above the base of the Gammon. The presence of these fossils so low in the Gammon can be explained by the southeastward replacement of noncalcareous Pierre lithology by calcareous Niobrara lithology (fig. 2).

\section{ELK BASIN AREA IN SOUTHERN MONTANA AND NORTHWESTERN WYOMING}

In the Elk Basin area in the northern part of the Bighorn Basin (fig. 1, loc. 14), rocks of Santonian and early Campanian age consist of the upper part of the Colorado Group (Niobrara and Carlile Shales), Telegraph Creek Formation, and Eagle Sandstone (Dobbin and others, 1944). (See fig. 3.) A ridge-forming

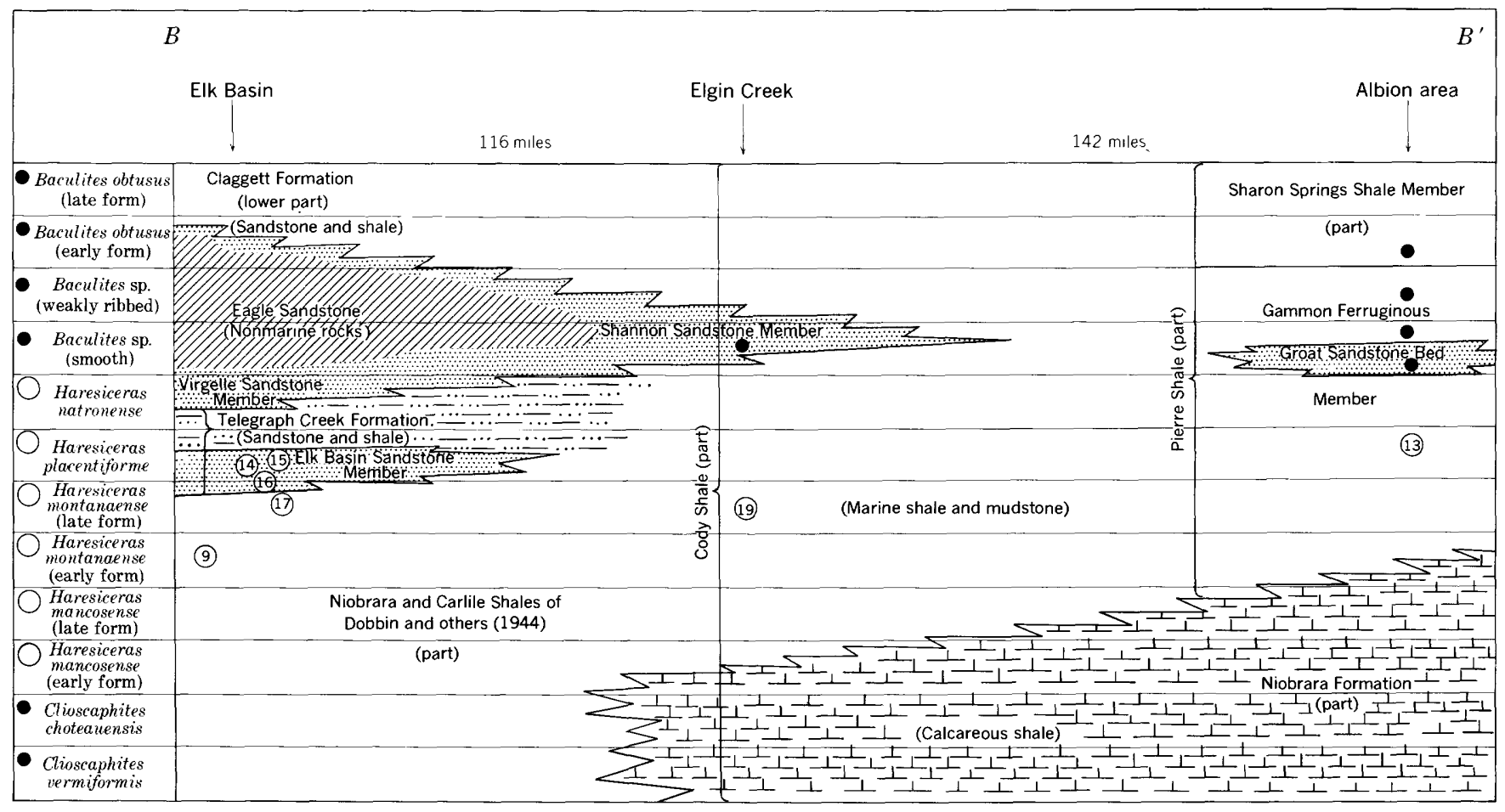

FIGURe 3.- Stratigraphic relations between Elk Basin in the northern part of the Bighorn Basin and the Albion area on the northeast flank of the Black Hills. Occurrences of Haresiceras are shown by circles enclosing their map locality numbers. Occurrences of guide fossils a little older or a little younger than Haresiceras that aided in constructing this cross section are indicated by large black dots. 
unit, the Elk Basin Sandstone Member, forms the base of the Telegraph Creek Formation. Calcareous concretions in the Elk Basin Sandstone Member have yielded many fossils including the type specimens of Reeside's Eutrephoceras alcesense, Haresiceras placentiforme, Scaphites levis, S. hippocrepis var. pusillus, $S$. aquilaensis var. nanus, and $S$. aquilaensis var. costatus (Reeside, 1927a, loc. 9625). Collections made recently from the upper part of the Elk Basin Sandstone Member by J. R. Gill include Inoceramus patootensis, one specimen of the fine-ribbed $S$. hippocrepis var. tenuis, and several examples of the coarse-ribbed var. crassus, including one individual that has well-defined rounded nodes and that is transitional to $S$. leei (pl. 1, figs. 28-30). Collections made earlier from just below the Elk Basin Sandstone Member by Geologica] Survey personnel include a slender form of Haresiceras montanaense (pl. 2, figs. 29, 30,37, 38) associated with a coarse-ribbed form of $S$. hippocrepis (fig. 1, locs. 16,17). The holotype of $H$. montanaense came from a lower stratigraphic position, 150 feet below the Elk Basin Sandstone Member about 12 miles north of the Elk Basin oil and gas field (fig. 1, loc. 9).

The faunal sequence in the Elk Basin area seems to be, in ascending order, (1) the stout coarse-ribbed form of Haresiceras montanaense; (2) a slender or later form of $H$. montanaense associated with coarse-ribbed Scaphites hippocrepis; and (3) H. placentiforme associated with Inoceramus patootensis and dominantly coarse ribbed forms of S. hippocrepis and S. aquisgranensis Schlüter [ $=S$. aquilaensis Reeside].

\section{HARDIN AREA IN SOUTH-CENTRAL MONTANA}

In the area of its outcrop east and south of Hardin (fig. 1) in Big Horn County, the Telegraph Creek, originally defined as a formation (Thom and others, 1935, p. 53), is treated now as a member of the Cody Shale (Richards, 1955 , p. 57). It overlies the Niobrara Shale Member which contains Clioscaphites vermiformis within 32 feet of the top. The Eagle Sandstone, which is massive and cliff forming at Billings west of Hardin, grades eastward into gray shale and mudstone that contain beds of ferruginous concretions, and in its outcrop area east of Hardin, the name Gammon Ferruginous Member of the Cody Shale is applicable.

Thom and others $(1935$, p. 54-56) recorded the occurrence of Desmoscaphites bassleri from the base, middle, and top of their Telegraph Creek Formation and Haresiceras (Mancosiceras) mancosense at the top (fig: 1, loc. 10) and in the " $* * *$ middle rim-forming Elk Basin sandstone" (fig. 1, loc. 8). In addition they found Uintacrinus sp. at the base, Inoceramus patootensis [as
I. aff. I. lobatus Goldfuss] in the middle, and Marsupites sp. at the top. In the area 20 miles or more west of Hardin where the Eagle Sandstone occurs, Thom and others $(1935$, p. 54) give a thickness of 320 feet for the underlying Telegraph Creek Formation. East of Hardin, where the Eagle Sandstone is absent owing to its passage into Gammon lithology, the most convenient boundary between the Telegraph Creek and Gammon Members is at a much higher stratigraphic level than farther west, and a thickness of 867 feet has been assigned to the Telegraph Creek by the writer (in Richards, 1955 , p. 57, 58). In this thick section of Telegraph Creek, Scaphites hippocrepis var. tenuis was collected 122 feet below the top, and Baculites aquilaensis was found about 70 feet below the top.

The lower part of the Gammon Ferruginous Member has not yielded megafossils in its area of outcrop east of Hardin, but a 6 -foot sandy unit 162 feet above the base of the member contains Scaphites hippocrepis and S. aquisgranensis Schlüter [as S. aquilaensis Reeside] (Richards, 1955, p. 60). Most of the specimens have fine dense ribbing (pl. 1, figs. 33-36) in contrast to the dominantly coarse ribbed forms known from the Elk Basin Sandstone Member of the Telegraph Creek Formation of Elk Basin (pl. 1, figs. 28-30). The fine ribbed scaphites in the Hardin area are associated with Glyptoxoceras rubeyi (Reeside) and baculites with very weak lateral ribs. The 51 feet of shale immediately overlying the 6 -foot sandy unit (Richards, 1955, p. 59) is characterized by smooth or nearly smooth baculites which represent the type of baculite found in part of the Gammon Shale on Porcupine dome. The rest of the Gammon (155 ft) contains baculites that have weak flank ribs like those in the uppermost part of the Gammon on Porcupine dome. The basal few feet of the overlying Claggett Shale Member contains a weakly ribbed early form of $B$. obtusus; the more strongly sculptured typical form of this species is found about 70 feet above the base.

The known sequence of fossils from rocks of middle Santonian to early Campanian age in the Hardin area can be summarized as follows: (1) Clioscaphites vermiformis, (2) Desmoscaphites bassleri and Haresiceras (Mancosiceras) mancosense associated with Inoceramus patootensis and Marsupites sp., (3) Scaphites hippocrepis var. tenuis and Baculites aquilaensis, (4) dominantly fine ribbed forms of $S$. hippocrepis and $S$. aquisgranensis associated with Glyptoxoceras rubeyi and very weakly ribbed baculites, (5) smooth baculites, (6) weakly ribbed baculites, (7) weakly ribbed early form of Baculites obtusus, and (8) more strongly sculptured late form of $B$. obtusus. 


\section{BUFFALO AREA IN NORTH-CENTRAL WYOMING}

Hose (1955, p. 93-99) described a thick section of the Cody Shale exposed along Elgin Creek, 10 miles southwest of Buffalo in Johnson County (fig. 1, loc. 19). He found Haresiceras montanaense associated with Baculites aquilaensis and dominantly coarse ribbed forms of Scaphites hippocrepis and S. aquisgranensis [as $S$. aquilaensis] in limestone concretions in the Cody Shale, 748 feet below the Shannon Sandstone Member of the Cody Shale (fig. 1, loc. 19; also see fig. 3). The specimens of Haresiceras were first identified by the writer as $H$. placentiforme. They are a little more slender than the specimens of $H$. montanaense associated with Scaphites leei on Porcupine dome (fig. 1, loc. 6-7) and are transitional to $H$. placentiforme. Much higher in the Cody Shale, from 75-382 feet below the Shannon Sandstone Member, Hose collected fine-ribbed forms of $S$. hippocrepis and $S$. aquisgranensis. Smooth baculites were found in the Shannon Sandstone Member.

\section{SALT CREER OIL FIELD IN EAST-CENTRAL WYOMING}

In the Salt Creek area in Natrona County (fig. 1, loc. 27), Wegemann $(1918$, p. 19, 20) recognized a calcareous unit which he called Niobrara Shale overlain by a noncalcareous gray unit which he called Steele Shale. Two sandstone units were noted in the Steele Shale, a lower thin fishtooth conglomeratic sandstone and an upper and thicker Shannon Sandstone Member. In recent years the name Steele has been restricted and not used in the Salt Creek area, and the name Cody has been applied. A third sandstone, the Sussex Sandstone Member of the Cody Shale, is recognized about 400 feet above the Shannon (Wilson, 1951).

The type specimen of Haresiceras natronense Reeside came from the Cody Shale, 200 feet below the Shannon Sandstone Member (Reeside, 1927a, loc. 10701). J. R. Gill carefully measured the Cody Shale at Salt Creek and collected many fossils. Ho found that about 600 feet of shale separates the unit locally known as the Fish-tooth sandstone from the Shannon Sandstone Member. Fine-ribbed forms of Scaphites hippocrepis were collected from 35 feet below the Fish-tooth sandstone to about 385 feet above it $(210 \mathrm{ft}$ below the Shannon). Glyptoxoceras rubeyi was found in the upper part of this range, although Reeside (1927a, locs. 10701-10703) recorded it on up into the Shannon Sandstone Member. Gill collected Baculites aquilaensis from 150 feet below the Fish-tooth sandstone to about 385 feet above it, a more weakly ribbed form of baculite in the next 65 feet of shale, and smooth baculites in the Shannon Sandstone Member. In the Sussex Sandstone Member and in the shale separating it from the Shannon
Sandstone Member, Gill found baculites that have weak flank ribs. Immediately above the Sussex, Gill measured 90-130 feet of bentonite-bearing shale that contains an early form of Baculites obtusus (weakly ribbed) in the lower part of the shale and the late or typical form (strongly ribbed) in the upper part.

\section{WIND RIVER BASIN IN WEST-CENTRAL WYOMING}

Haresiceras has been found in three areas in the Wind River Basin: (1) near Shotgun Butte on the northwest side of the Basin (fig. 1, locs. 23, 24), (2) near Lander on the southwest side (fig. 1, loc. 28), and (3) near Conant Creek on the south side (fig. 1, locs. 29, 30). The localities near Shotgun Butte and Conant Creek provide the most data concerning stratigraphic relations (fig. 4 ).

Keefer and Troyer (1956) measured a detailed section of the Cody Shale near Shotgun Butte on the north side of the Wind River Basin. Here the Cody Shale consists of a lower shaly member 1,560 feet thick and an upper sandy member 2,190 feet thick. Keefer and Troyer found Clioscaphites vermiformis 330 feet above the base of the sandy member and Haresiceras (Mancosiceras) mancosense, Desmoscaphites bassler, and Scaphites leei, associated with the free-swimming crinoids Vintacrinus and Marsupites, 900 feet above the base (fig. 1, loc. 23). At 1,660 feet above the base (fig. 1, loc. 24), they found Haresiceras montanaense (originally identified by the writer as $H$. placentiforme) and the septate coils of Scaphites hippocrepis and $S$. aquisgranensis [as S. aquilaensis]. At 2,120 feet above the base of the sandy member ( $75 \mathrm{ft}$ below the top), Keefer and Troyer collected Inoceramus patootensis [as $I$. lundbreckensis], Baculites aquilaensis, and the coarseribbed Scaphites hippocrepis var. crassus Reeside.

Near Conant Creek, about 60 miles southeast of Shotgun Butte, Yenne and Pipiringos (1954) found Haresiceras montanaense (identified by the writer as Puzosia mancosensis Reeside) associated with Scaphites hippocrepis var. tenuis in the middle part of the sandy member of the Cody Shale (fig. 1, loc. 29). Higher in the sandy member, Yenne and Pipiringos found fine-ribbed forms of $S$. hippocrepis and $S$. aquisgranensis [as $S$. aquilaensis] and, more recently, Haresiceras natronense and Glyptoxoceras mbeyi have been found apparently in this part of the Cody (fig. 1, loc. 30). The overlying Mesaverde Formation is split into a lower and an upper part by a tongue of marine shale. Baculites from the lower part of the Mesaverde consist of noded juveniles and smooth adults that were identified originally by the writer as $B$. asper Morton, $B$. minerensis Landes, and $B$. haresi Reeside; these are interpreted now as representing various growth stages of the smooth species 


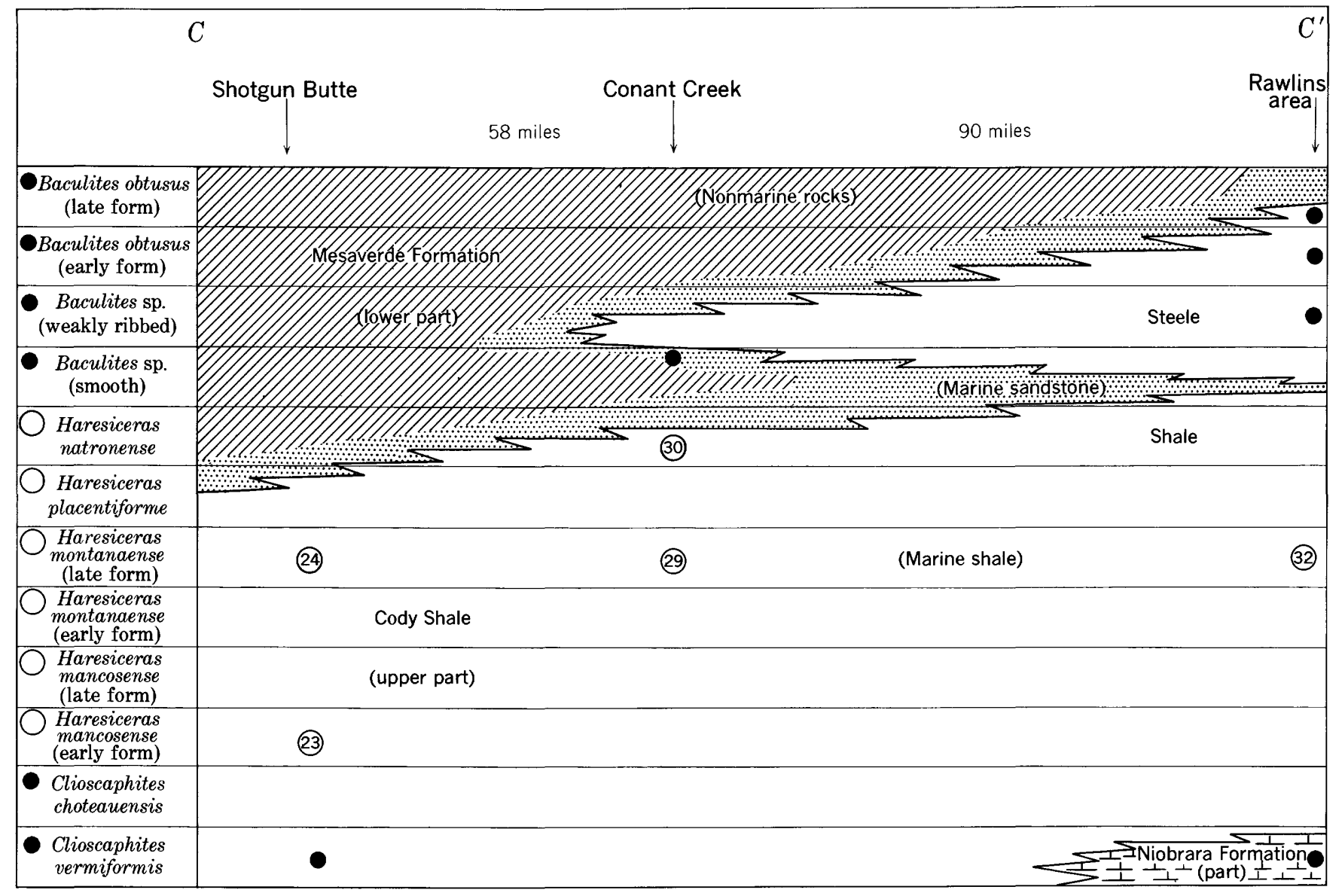

FIgore 4.- Stratigraphic relations between part of the Santonian and Campanian rocks of the Wind River Basin (Shotgun Butte and Conant Creek) and the time-equivalent rocks near Rawlins. Occurrences of Haresiceras are shown by circles enclosing their map locality numbers. Occurrences of guide fossils a little older or a little younger than Haresiceras that aided in constructing this cross section are indicated by large black dots.

that characterizes the Shannon Sandstone Member of the Cody Shale and Groat Sandstone Bed of the Pierre Shale and equivalent rocks. The small undescribed flat-ventered scaphite known from the Groat (p. I 7) has been found near Conant Creek in the lower part of the Mesaverde.

\section{GREEN RIVER AREA IN EAST-CENTRAL UTAH}

In the belt of Mancos Shale cropping out between the town of Green River and the Book Cliffs (fig. 1), Fisher and others $(1960$, pl. 10) found Clioscaphites vermiformis $1,350-1,525$ feet above the base of the Mancos Shale, Desmoscaphites bassleri 1,710-1,920 feet above the base, and Scaphites hippocrepis about 2,8003,200 feet above the base. Haresiceras (Mancosiceras) mancosense was found with $D$. bassleri and Inoceramus patootensis 1,710 feet above the base of the Mancos Shale (fig. 1, loc. 38), and Haresiceras fisheri was found with $S$. hippocrepis about 2,800 feet above the base (fig. 1, loc. 39).

\section{SUMMARY OF FAUNAL SEQUENCES}

By combining the data provided by each of the selected sequences of fossils, the following succession of forms, from youngest to oldest, is apparent from rocks of middle Santonian to early Campanian age.

Baculites obtusus (late or strongly ribbed form) obtusus (early or weakly ribbed form) sp. (adults with weak flank ribs) sp. (adults smooth)

Dominantly fine ribbed forms of Scaphites hippocrepis and S. aquisgranensis associated with Haresiceras natronense, $H$. fisheri, Glyptoxoceras rubeyi, and baculites either smooth or with weak flank ribs.

Dominantly coarse ribbed forms of $S$. hippocrepis and $S$. aquisgranensis associated with Haresiceras placentiforme, Baculites haresi or B. aquilaensis, and Inoceramus patootensis.

Dominantly coarse ribbed forms of $S$. hippocrepis and $S$. aquisgranensis associated with Baculites aquilaensis and a late form of Haresiceras montanaense.

Early form of Haresiceras montanaense associated with Scaphites leei and Baculites haresi.

Late form of Haresiceras (Mancosiceras) mancosense 
associated with S. leei, B. haresi, Desmoscaphites bassleri, Inoceramus patootensis, Marsupites sp., and Uintacrinus socialis. Early form of $H$. (M.) mancosense associated with S. leei, B. thomi, D. erdmanni, I. patootensis, and Uintacrinus spcialis. Clioscaphites choteauensis

Clioscaphites vermiformis and Inoceramus cordiformis

In this sequence of fossils, Haresiceras is found immediately above the highest Clioscaphites and apparently ranges on up through the Scaphites hippocrepis Range Zone. It is not found in the younger rocks that are characterized by species of baculites.

Two forms are assigned to Haresiceras (Mancosiceras) mancosense; one has the venter of the late juvenile whorls rounded as in the holotype, and the other has a flattened venter. The round-ventered form seems to be associated with both Desmoscaphites erdmanni and $D$. bassleri, whereas the flat-ventered form has been found only with $D$. bassleri.

Haresiceras montanaense occurs as a stout form associated with Scaphites leei at one locality and as a more slender form associated with dominantly coarse ribbed specimens of $S$. hippocrepis in other localities. Inasmuch as $H$. montanaense has not been found with Desmoscaphites bassleri, it is assigned to the lowest part of the S. hippocrepis Range Zone.

Haresiceras placentiforme has been found with coarse forms of S. hippoorepis but not with S. leei. It seems to lie in the middle part of the S. hippocrepis Range Zone.

Haresiceras natronense is known only with fineribbed forms of S. hippocrepis and is assigned to the uppermost part of the $S$. hippocrepis Range Zone. Likewise, $H$. fisheri seems to lie high in this zone (Fisher and others, 1960 , pl. 10).

Aside from Desmoscaphites and Scaphites hippocrepis, important fossils associated with Haresiceras are Inoceramus patootensis, Scaphites leei, Baculites haresi, and B. aquilaensis. Inoceramus patootensis and Scaphites leei, first appear in the Desmoscaphites erdmanni Range Zone and persist on up into the Scaphites hippocrepis Range Zone; I. patootensis is not known above the middle of the zone and S. leei may be restricted to the lower part. Baculites haresi first appears in the Desmoscaphites bassleri Range Zone and ranges on up into the middle of the Scaphites hippocrepis Range Zone. Baculites aquilaensis seems to be confined to the S. hippocrepis Zone.

\section{AGE OF HARESICERAS}

Haresiceras, as defined in this paper, ranges in age from late Santonian to early Campanian. All the species except $H$. mancosense are assigned to the Campanian.
The oldest species, $H$. mancosense, is associated with the free-swimming crinoids Uintacrinus and Marsupites which, in Europe, are guide fossils to the upper part of the Santonian Stage. Haresiceras fisheri, H. natronense, $H$. placentiforme, and the younger form of $H$. montanaense, are associated with Scaphites hippocrepis which is a well-accepted index fossil in Europe for rocks of early Campanian age. The early form of Haresiceras montanaense from Porcupine dome in eastcentral Montana (fig. 1, locs. 6,7) is younger than the upper zone of the Santonian Stage that has Marsupites and Uintacrinus and older than strata containing the first appearance of Scaphites hippocrepis. This form of Haresiceras montanaense possibly lies in the Diplacmoceras bidorsatum Zone which is the oldest zone recognized in the Campanian Stage in Europe. The possible arrangement of the species of Haresiceras in regard to the commonly accepted European guide fossils of the late Santonian and early Campanian Stages is shown in table 2 as follows.

TABLE 2.-Possible correlation of the zones of Haresiceras to the late Santonian and early Campanian faunal zones in Europe

\begin{tabular}{|c|c|c|c|}
\hline \multicolumn{2}{|c|}{ Stage } & European guide fossils & Western Interior guide fossils \\
\hline \multirow{4}{*}{ 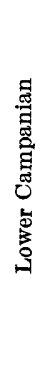 } & \multirow{3}{*}{ 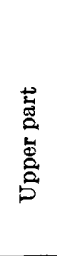 } & \multirow{3}{*}{$\begin{array}{l}\text { Scaphites hippocrepis, S. aqu- } \\
\text { isgranensis, S. binodosus, } \\
\text { and Gonioteuthis quadrata. }\end{array}$} & $\begin{array}{l}\text { Haresiceras natronense, H. fisheri, and } \\
\text { fine-ribbed forms of Scaphites hippo- } \\
\text { crepis and S. aquisgranensis. }\end{array}$ \\
\hline & & & $\begin{array}{l}\text { Haresiceras placentiforme and coarse- } \\
\text { ribbed forms of Scaphites hippocrepis } \\
\text { and S. aquisgranensis. }\end{array}$ \\
\hline & & & $\begin{array}{l}\text { Haresiceras montanaense (late form) and } \\
\text { coarse-ribbed forms of Scaphites } \\
\text { hippocrepis and S. aquisgranensis. }\end{array}$ \\
\hline & 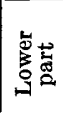 & $\begin{array}{l}\text { Diplacmoceras bidorsatum, } \\
\text { Hauericeras pseudogardeni, } \\
\text { and Gonioteethis granulata } \\
\text { (typical form). }\end{array}$ & $\begin{array}{l}\text { Haresiceras montanaense (early form) } \\
\text { and Scaphites leei. }\end{array}$ \\
\hline \multicolumn{2}{|c|}{ 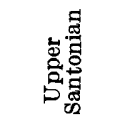 } & $\begin{array}{l}\text { Placenticeras syrtale, Marsu- } \\
\text { pites spp. Uint G crinus } \\
\text { spp., and Gonioteuthis gran- } \\
\text { ulata (early form). }\end{array}$ & $\begin{array}{l}\text { Haresiceras mancosense, Scaphites leei, } \\
\text { Desmoscaphites spp., Marsupites sp., } \\
\text { and Uintacrinus socialis. }\end{array}$ \\
\hline
\end{tabular}

In regard to the dominance of fine-ribbed forms of Scaphites hippocrepis and $S$. aquisgranensis higher in the sequence of Western Interior fossils than coarseribbed forms, it is interesting to note that Grossouvre $(1893$, pl. 31, 32, 35, 37) figured both types from the Campanian of France but he did not indicate a stratigraphic separation.

\section{ORIGIN OF AND EVOLUTION WITHIN HARESICERAS}

Haresiceras is known only from the upper Santonian and lower Campanian rocks of the Western Interior region. Reeside $(1927 \mathrm{a}$, p. 17,18$)$ offered no explanation concerning the origin of his genus although he noted some resemblances to Placenticeras, Hoplites, Metaplacenticeras, Forbesiceras, and Sonneratia. He 
assigned the genus to the subfamily Hoplitinae of the family Kosmoceratidae owing to certain similarities of Haresiceras to Hoplites such as the similar shape of the lateral ribs and whorl sections as well as some resemblance in parts of the suture. Basse $(1952$, p. 659) and Wright (1957, p. L392), on the other hand, assigned Haresiceras to the family Placenticeratidae Hyatt because of the compressed whorls, flat venter, weak sculpture, and " $* * *$ suture with adventive and auxiliary elements."

The older species of Haresiceras have some characters in common with Desmoscaphites and Clioscaphites such as similar suture pattern and type of ribbing (fig. 5). The writer believes the origin of Haresiceras is to be found in the Santonian scaphites of the Western Interior.

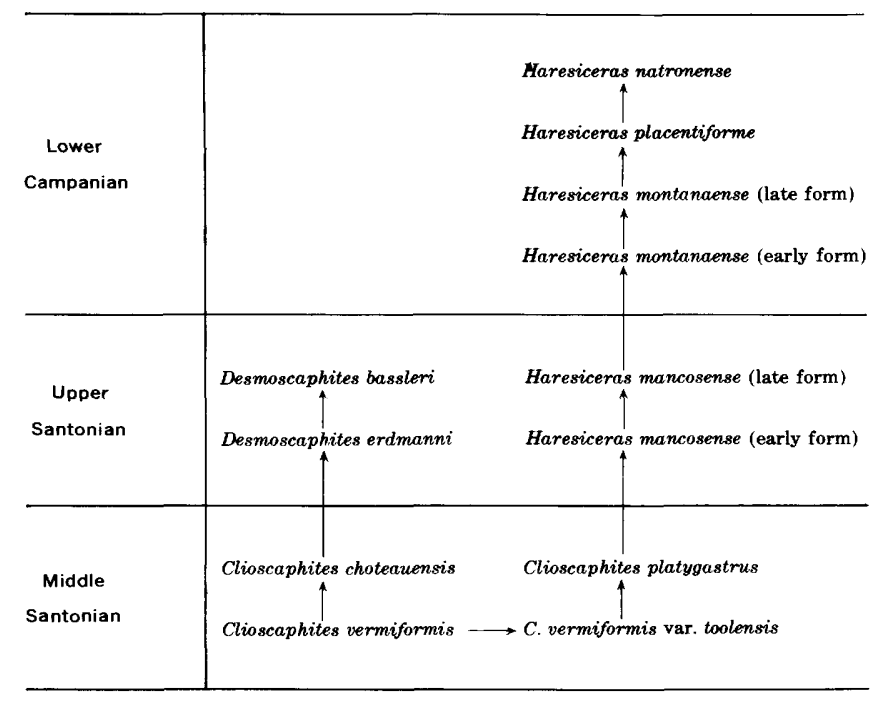

Figure 5.-Lineages of Clioscaphites, Desmoscaphites, and Haresiceras and probable origin of Haresiceras from Clioscaphites.

'During latest Turonian time the Western Interior scaphites tended to become less unrolled in the adult stage and this trend continued through the Coniacian and Santonian (Cobban, 1951b, p. 11 and fig. 2). By the beginning of Santonian time the entire dorsum of the adult body chamber was in contact with the venter of the last septate whorl. There was a corresponding change in the size of the umbilicus which became greatly reduced in the middle and late Santonian.

Near the close of the Turonian, the main stock of Western Interior scaphites split into two lines. One lineage was characterized by species that had at first high primary ribs on the adult body chamber and later a row of ventrolateral nodes. The other lineage consists of scaphites that never developed nodes. The lineage of noded scaphites departed further from the line of nodeless scaphites during middle Santonian time by the ribbing on the internal whorls developing a pronounced forward arching on crossing the venter.

Clioscaphites vermiformis (Meek and Hayden) represents the noded line of scaphites during the early part of the middle Santonian. In this species the dorsum of the body chamber is entirely in contact with the venter of the last septate whorl, the umbilicus is very small, and the ribs cross the venter on the internal whorls with a forward arching (pl. 1, figs. 11-13). The adults have a considerable range in stoutness from the more slender form of the holotype to the very broad variety toolensis Cobban (for illustrations of these forms see Cobban, $1951 \mathrm{~b}$, pls. 18, 19). The variety toolensis has a very broadly rounded venter and well-defined ventrolateral shoulder.

By the later part of middle Santonian time the broadventered form of $C$. vermiformis seems to have given rise to a nearly flat-ventered species, $C$. platygastrus Cobban (1951b. p. 36, pl. 20, figs. 12-16; also pl. 3, figs. 10-13 of this report), whereas the more round-ventered and slenderer form of the species developed into $C$. choteauensis Cobban (1951b, p. 38, pl. 20, figs. 8-11) by having the adult body chamber more densely ribbed and the internal whorls more compressed. (Compare figs. 9 and 12 on pl. 1.)

Desmoscaphites erdmanni developed out of $C$. choteauensis by the adult body chamber becoming more densely ribbed, by the internal whorls being more compressed (compare figs. 2 and 9 on pl. 1), and by the loss of ribbing on the early juvenile whorls accompanied by the sudden appearance of constrictions (pl. 1, figs. 2, 3). A parallel development of this is the probable descent of Haresiceras (Mancosiceras) mancosense from Clioscaphites platygastrus. The early septate whorls of $H$. (M.) mancosense have constrictions similar to those on D. erdmanni (compare figs. 3, 4, 25, 26 on pl. 1) and there is a tendency toward loss of ribbing on these early whorls.

The younger form of $H$. (M.) mancosense (pl. 2, figs. 41-48) reveals an earlier appearance of a flattened venter on the septate whorls but ventrolateral nodes are confined to the adult body chamber. The adults are more compressed than their probable $C$. platygastrus ancestor and the ribbing is weaker.

The early form of $H$. montanaense developed out of the late form of $H$. (M.) mancosense by an acceleration in the appearance of a flattened venter early on the septate whorls, by the ventral flattening being more conspicuous, by the presence of ventrolateral nodes on the septate whorls as well as on the body chamber, and by a narrowing of the venter on the body chamber and further weakening of the sculpture there. Con- 
strictions tend to disappear; they are present only on the early whorls of some individuals.

The late form of $H$. montanaense descended from the early form by further narrowing of the whorl sections and continuing the trend toward loss of ribbing and reduction in size of the ventrolateral nodes. Constrictions may have disappeared.

Haresiceras placentiforme (pl. 3, figs. 1-6) developed out of the late form of $H$. montanaense by further reduction in the strength of the ribbing and in the size of the ventrolateral nodes. The ribs are nearly of equal height and are confined to the ventrad half of the flank. The venter, which was slightly arched on older species, is perfectly flat on $H$. placentiforme.

Haresiceras natronense (pl. 3, figs. 14-21) continues the trend toward compression of the whorls. The venter is flat or even slightly concave. With the exception of the apertural end of the shell, ribbing is of uniform height and spacing and is confined to the outer part of the flank.

Comparison of the sutures of Clioscaphites, Desmoscaphites, and Haresiceras reveals a similarity in the overall pattern (fig. 6). In general the lobes and saddles trend toward lengthening and deeper folding in the younger species.

The trifid lateral lobes of Clioscaphites developed out of the bifid lateral lobes of Scaphites by rotation of the umbilical side of the lobes toward the venter (Cobban, $1951 b$, p. 11 and fig. 3). The suture of $C$. vermiformis has the lobes and saddles decreasing uniformly in size away from the first lateral saddle; the second lateral saddle tends to be wider than the first lateral lobe, and the third lateral saddle is broader than the second lateral lobe (fig. 6). In the lineage, $C$. vermiformis- $D$. bassleri, the second lateral lobe migrates toward the venter causing a corresponding reduction in size of the second lateral saddle; this reduction is such that in the suture of $C$. choteauensis the lobe and saddle are of equal size, but in the younger Desmoscaphites, the saddle is smaller than the lobe (fig. 6). A parallel of this change is seen in the suture patterns of the lineage, $C$. vermiformis var. toolensis-Haresiceras natronense. The first lateral lobe and second lateral saddle are of equal size in $C$. vermiformis var. toolensis, but in $C$. platygastrus the saddle is a little smaller than the lobe and becomes increasingly smaller in the species of Haresiceras (fig. 6). The second lateral saddle is symmetrically bifid through most of this lineage $(C$. vermiformis var. toolensis- $H$. montanaense), but in the younger species the branch nearest the venter becomes smaller and migrates downward imparting a distinctive asymmetry to the saddle.
Another interesting evolutionary change takes place in the sutures of Haresiceras. The third and fourth lateral lobes remain small, but the third and fourth lateral saddles widen to such an extent that in the younger species the third lateral saddle surpasses the second lateral saddle in width which is the reverse condition in Clioscaphites. In addition to the widening of the third and fourth lateral saddles, the lobes that bifurcate these saddles lengthen and enlarge to such an extent that they almost match the third and fourth lateral lobes (pl. 3, figs. 4, 17).

\section{SYSTEMATIC DESCRIPTIONS \\ Class Cephalopoda \\ Family Scaphitidae Meek, 1876 \\ Genus Haresiceras Reeside, 1927}

Reeside's original description of this genus is as follows:

The fundamental generic characters combined in this genus are compressed whorls with flat venter bordered by two rows of nodes, very narrow umbilicus, and subparallel flanks; obscure sigmoid ribs curving sharply forward from the umbilicus to the middle or the flank, then passing radially to the venter, and crossing it uninterrupted but with a forward bend; suture with long triangular first lateral lobe and numerous auxiliary lobes.

The present writer adds to the generic description the following observations concerning the adolescent whorls and the suture pattern. The early whorls of the older species have rounded venters and weak constrictions, whereas those of the younger species have flattened venters and no constrictions. The suture is complex and has four or five trifid lateral lobes separated by bifid saddles; the first lateral saddle is typically scaphitid in its large size and form.

\section{Haresiceras placentiforme Reeside}

Plate 3, figures 1-6: text figure 7

1927. Haresiceras placentiforme Reeside, U.S. Geol. Survey Prof. Paper 151, p. 18, pl. 13, figs. $1-14$; pl. 45, fig. 4. 1952. Haresiceras placentiforme Reeside. Basse, in Piveteau, Traité de Paléontologie, v. 2, p. 659, fig. 54-18.

1957. Haresiceras placentiforme Reeside. Wright, in Moore, Treatise on Invertebrate Paleontology, pt. L, Mollusca 4, p. L392, figs. 510, 5a-c.

1960. Haresiceras placentiforme Reeside. Easton, Invertebrate Paleontology, figs. 11.31-6a, 6b.

The adult of this species is characterized by very weak flank ribbing and a moderately broad flat venter bordered by a finely nodose ventrolateral keel.

The species has been described very thoroughly by 


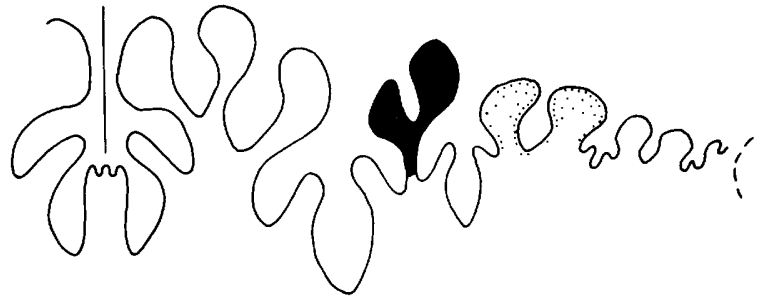

Haresiceras natronense

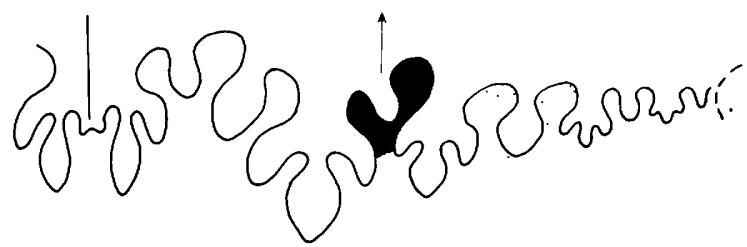

Haresiceras placentiforme

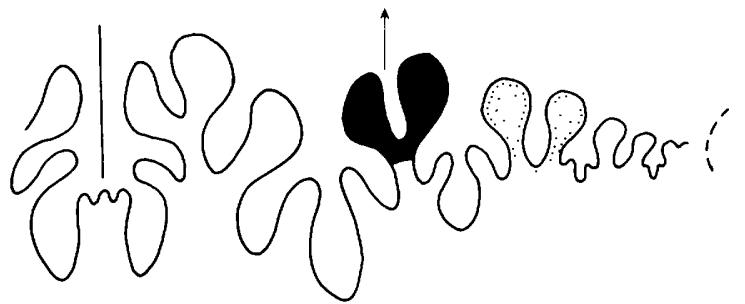

Haresiceras montanaense

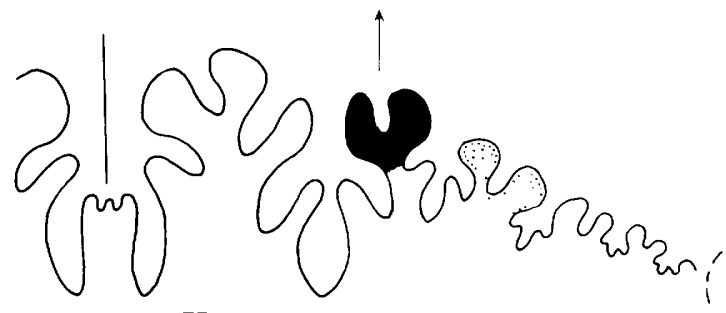

Haresiceras mancosense

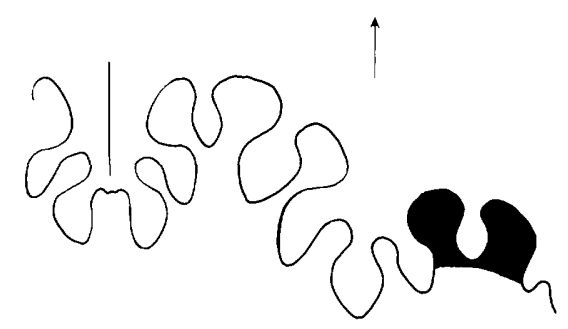

Clioscaphites platygastrus

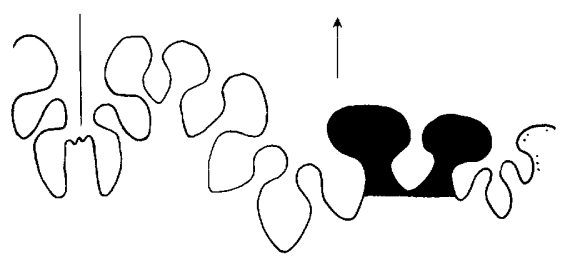

Clioscaphites vermiformis var. toolensis

Figure 6.-Drawings of sutures (simplified) illustrating changes in width and form of the second lateral saddle (solid black) and third lateral saddle (stippled) of species of Clioscaphites, Desmoscaphites, and Haresiceras (compare with fig. 5). 
Reeside who made the following statements regarding the growth forms:

Whorls up to a diameter of 3.5 millimeters (21/2 whorls) stout, at first wider than high, then circular in cross section. From this stage to that at a diameter of 15 millimeters ( $4 \frac{1}{6}$ whorls) the whorl increases in relative height, the flanks flatten, and finally the venter begins to flatten. At the stage with diameter of 15 millimeters a pair of nodose keels appears bordering the flattened venter, and the cross section of the whorl takes on the quadrate aspect maintained in all the later stages.
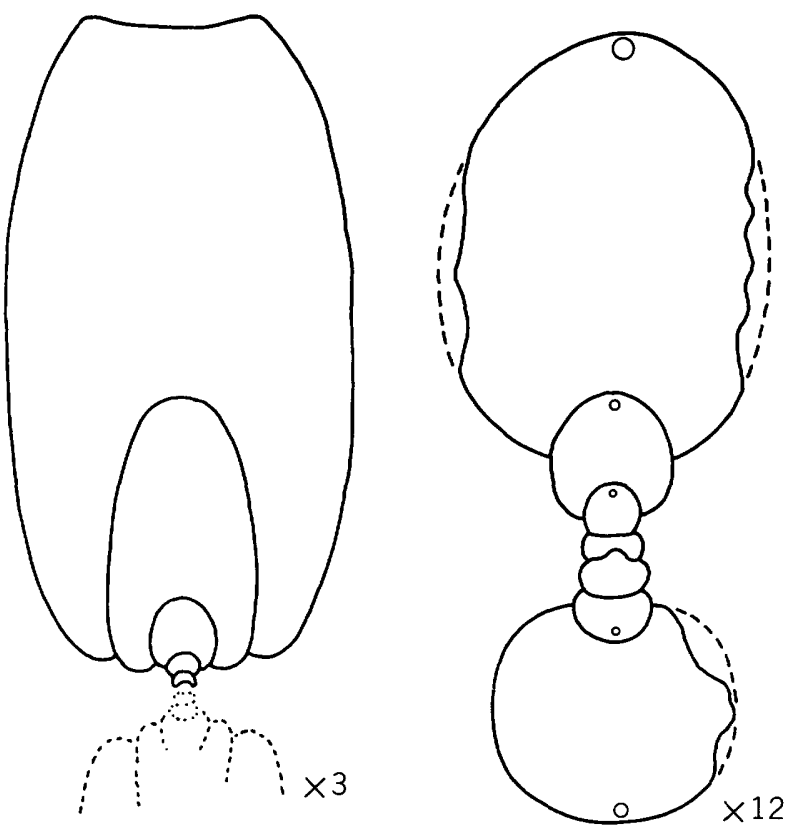

Figdre 7.-Cross sections, $\times 3$ and $\times 12$, of Haresiceras placentiforme Reeside (after Reeside). USNM 73317.

Regarding the form of the adult, Reeside noted that the umbilicus was very small (one-thirtieth the diameter of the largest specimens), the umbilical shoulder was rounded, and the aperture was sinuous and followed the shape of the ribs. Reeside observed also that ribs first appeared on the flanks at a diameter of 11 or $12 \mathrm{~mm}$ and that ventral ribs appeared at a slightly larger diameter.

The venter and adjoining part of the flank on the older half of the holotype is badly weathered and the ribbing is obscured. A very well preserved septate coil (pl. 3, figs. 1-4) of comparable size from the Pierre Shale of the Black Hills reveals the sculptural details not seen on the holotype. The half whorl ending at a diameter of about $18 \mathrm{~mm}$ has 20 moderately strong ventral ribs of even height and spacing. At that diameter the ribbing changes abruptly by becoming denser, weaker, and of uneven height. The half whorl beginning at a diameter of $18 \mathrm{~mm}$ and ending at $28.5 \mathrm{~mm}$ has about 40 ventral ribs. On the entire whorl the ribs on the flank are strongest near the ventrolateral border and weaken and disappear toward the umbilicus. This loss of ribbing toward the umbilicus was observed on the younger part of the holotype by Reeside who thought it might be due to the condition of preservation of the specimen. In addition to the change to irregular and denser ribbing at a diameter of about $18 \mathrm{~mm}$ on the Black Hills specimen, secondary ribs appear as well as a clearly defined nodose ventrolateral keel. The nodes are very small, clavate, and irregular in size, the largest and highest being on the strongest ribs.

The suture is perfectly exposed on the specimen from the Black Hills and reveals an interesting pattern (pl. 3, fig. 4). The ventral lobe is broad and bifid. The first lateral saddle is as large as the ventral lobe and very asymmetrically bifurcated by a deep trifid lobe. The first lateral lobe is trifid and about as long as the ventral lobe but not as wide. The second lateral saddle is high, narrower than the first lateral lobe, and very asymmetrically bifurcated by a deep trifid lobe. The second lateral lobe is trifid, shorter than the first lateral lobe and half as wide. The third lateral saddle is broader and shallower than the second lateral lobe and deeply bifurcated by a large trifid lobe. The third lateral lobe is trifid, almost as wide as the second lateral lobe but only half as long. The fourth lateral saddle is half as large as the third lateral saddle and deeply bifurcated by a trifid lobe. The fourth lateral lobe is trifid and half as large as the third lateral lobe.

Occurrence: The holotype came from the Elk Basin Sandstone Member of the Telegraph Creek Formation in the Elk Basin oil field in Park County, Wyo. (fig. 1, loc. 14). Other specimens are known from this sandstone in the northern part of the Bighorn Basin in Wyoming (fig. 1, locs. 15, 18). The species has been found also in the upper part of the Cody Shale in the southeastern part of the Bighorn Basin (fig. 1, loc. 25), in the Gammon Ferruginous Member of the Pierre Shale around the northern half of the Black Hills (fig. 1, locs. 11-13, 20-22, 33), and in the upper part of the Smoky Hill Shale Member of the Niobrara Formation in southeastern Colorado (fig. 1, loc. 42).

Types: Holotype USNM 73317; plesiotypes USNM 131483, 131484.

\section{Haresiceras natronense Reeside}

Plate 3, figures 14-21

1927. Haresiceras natronense Keeside, U.S. Geol. Survey Prof. Paper 151, p. 19, pl. 14, figs. 4-16.

Very compressed whorls and conspicuous ribbing characterize this species. The venter flattens and is bordered by nodose keels at a very small diameter.

Reeside observed the following changes in the growth forms of this species:

Earliest whorls well rounded and relatively stout, increasing in relative height until at a diameter of 8 or 9 millimeters the whorls have distinctively flattened fianks, the venter becomes 
flattened and the nodose keels appear. The cross section in the subsequent stages has a quadrate aspect.

Reeside recorded the presence of faint lateral ribs on a whorl of only $2 \mathrm{~mm}$ diameter and that the succeeding whorl had well-marked ribs at a diameter of $6 \mathrm{~mm}$. He noted that as growth continued these lateral ribs spread across the venter and were very distinct there at a diameter of 7 or $8 \mathrm{~mm}$. The holotype, a juvenile of $16.5 \mathrm{~mm}$ diameter, has a well-defined flat venter bordered by nodose keels at a diameter of $9 \mathrm{~mm}$.

The largest collections at hand came from the Gammon Ferruginous Member of the Pierre Shale on the east side of the Black Hills (fig. 1, locs. 34, 35). These lots contain about 25 specimens, chiefly crushed adults (pl. 3, figs. 17-21). The few uncrushed juveniles of less than $20 \mathrm{~mm}$ diameter reveal considerable variation in stoutness and diameter at which the venter flattens $(10-14 \mathrm{~mm})$. As in Haresiceras placentiforme the lateral ribs are strongest near the margin of the venter but weaken and disappear toward the umbilicus. These ribs cross the venter with uniform height and spacing up to a diameter of 20 or $21 \mathrm{~mm}$ where those crossing the venter become weaker, denser, and irregular in height and spacing. Where they cross the ventrolateral keel the weaker ribs bear smaller nodes than the stronger ribs. Lateral rib counts for the complete whorls of two of the figured specimens are 50 at a diameter of $26.5 \mathrm{~mm}$ (pl. 3, fig. 14) and 44 at a diameter of $31.5 \mathrm{~mm}$ (pl. 3, figs. 18, 21).

Reeside did not illustrate the suture. The suture figured here (pl. 3, fig. 17) is from near the end of the septate coil of a large adult from figure 1, locality 35. Except for having longer and more deeply digitate elements, the suture resembles that of $H$. placentiforme.

Occurrence. The holotype is from the Cody Shale $200 \mathrm{ft}$ below the Shannon Sandstone Member in the Salt Creek oil field, Natrona County, Wyo. (fig. 1, loc. 27). The species is known elsewhere from the Cody Shale near Kaycee, Wyo. (fig. 1, loc. 26), from the upper part of the Cody Shale in the Wind River Basin in central Wyoming (fig. 1, loc. 30), from the Gammon Ferruginous Member of the Pierre Shale on the east side of the Black Hills in western South Dakota (fig. 1, locs. 34, 35), from the upper part of the Mancos Shale in northwestern Colorado (fig. 1, loc. 40), and questionably from near the top of the Smoky Hill Shale Member of the Niobrara Formation near Boulder, Colo. (fig. 1, loc. 41).

Types: Holotype USNM 73320; plesiotypes USNM 131485-131487.

\section{Haresiceras fisheri Reeside}

Plate 3, figures 7-9

1927. Haresiceras fisheri Reeside, U.S. Geol. Survey Prof. Paper 151, p. 19, pl, 45, figs. 1-3.

This form is known only from the holotype, a septate coil with about three-fifths of the body whorl. The specimen is very compressed, conspicuously ribbed, and further characterized by an unusually narrow venter.
The venter is rounded up to a diameter of $20 \mathrm{~mm}$ but truncated at larger diameters. The umbilicus is very small and the umbilical shoulder rounded. The ventral half of the flattened flanks is crossed by ribs of which every third or fourth is more elevated than the others. At the ventrolateral margin each rib is raised into a small node. About 40 ribs cross the venter on the last half whorl. Reeside did not figure the suture and noted that it was not well preserved.

This form most closely resembles $H$. natronense by its compressed cross section, narrow venter, and conspicuous ribbing. Possibly it is no more than a variant. Its association with Scaphites hippocrepis and its stratigraphic position high in that Range Zone (Fisher and others, 1960, p. 29, pl. 10) seems comparable to that of $H$. natronense.

Occurrence: The holotype and only specimen came from about $800 \mathrm{ft}$ below the top of the Mancos Shale near Green River, Emery County, Utah (fig. 1, loc. 39).

Type: Holotype USNM $\mathbf{7 3 3 8 7 .}$

\section{Haresiceras montanaense (Reeside) \\ Plate 2, figures $1-40$}

1927. Acanthoceras? montanaense Reeside, U.S. Geol. Survey Prof. Paper 151, p. 20, pl. 22, figs. 1-4.

Reeside based this species on a single poorly preserved specimen, a partly crushed and distorted young adult. This specimen, about $22 \mathrm{~mm}$ in diameter, has flattened flanks, a very broad gently arched venter, and a sharply defined ventrolateral edge. The flank on the last half whorl has about 12 moderately high ribs that curve back from the umbilicus, then arch forward on the outer part of the flank and finally straighten to the ventrolateral border. The ribs then cross the venter with a forward arching. Each rib is raised into a small node at the ventrolateral margin, and the resulting row of nodes resembles a false keel.

The writer has at hand about 50 specimens, chiefly juveniles, that seem assignable to Reeside's species. These can be divided into an older stout form associated with Scaphites leei and a younger and more slender form associated with coarse-ribbed Scaphites hippocrepis. Reeside's holotype is typical of the older form.

The older form is represented best by a collection of 35 uncrushed juveniles 8-17 $\mathrm{mm}$ in diameter that came from a limestone concretion in the Gammon Shale on Porcupine dome in east-central Montana (fig. 1, loc. 7). These specimens reveal much variation in the degree of stoutness and in the diameter at which ribbing and the ventrolateral shoulder first appear (pl. 2, figs. 13-24). In general the stouter the specimen the smaller the diameter at which ribbing and the ventrolateral shoulder appear. This suggests that the stouter adults should be smaller than the more slender adults. (For comparable examples, see Reeside and Cobban, 1960.) 
A distinct ventrolateral shoulder first appears at a diameter of from 6 to $11 \mathrm{~mm}$ and ribbing appears at slightly larger diameters $(7-12 \mathrm{~mm})$. The ribs appear first on the venter and adjoining part of the flank, and within the next half whorl, the ribs extend across the flank to the umbilicus. Nodes rise from the ventrolateral edge within the next quarter of a whorl following the initial rise of ribbing. Constrictions are present at diameters less than $12 \mathrm{~mm}$ on internal molds of a few specimens. These constrictions follow the shape of the ribs, number five or less per whorl, and are present only on the venter and outer part of the flank. On some individuals the constrictions occur in pairs in which the constrictions of a pair are closely spaced but separated by a high rib. On other specimens the constrictions may be single and bounded by high ribs or they may be single without accompanying ribs.

The younger form of Haresiceras montanaense is represented best by a few very well preserved specimens from limestone concretions in the Cody Shale at Elgin Creek in Johnson County, Wyo. (fig. 1, loc. 19). Three of these specimens are shown on plate 2 , figures 5,35 , 39. These specimens as well as other examples differ from the older form of $H$. montanaense chiefly by being a little more compressed and having weaker ribbing.

Two specimens of the late form of $H$. montanaense from Park County, Wyo., have adult body chambers. One is a small individual, $27 \mathrm{~mm}$ in diameter from figure 1, locality 17, that is crushed but otherwise complete (pl. 2, figs. 29, 30). Its body chamber includes three-fourths of the last whorl. The ribs on the venter and flanks of the chambered part are uniform in height and spacing, but on the body chamber they are differentiated into stronger primaries that extend to the umbilicus and weaker secondaries that trend from the ventrolateral margin $1 / 3-1 / 2$ of the distance to the umbilicus before fading away. Near the aperture many weak intercalaries appear on the venter and flank and each bears a very small node at the ventrolateral edge. The aperture is sinuous following the shape of the ribs. The other body chamber is from figure 1 , locality 16, and represents a large individual of possibly $50 \mathrm{~mm}$ diameter (pl. 2, figs. 37, 38). This specimen shows numerous intercalated ribs near the aperture and a general weakening of the ribbing there.

The suture of $H$. montanaense cannot be distinguished on the holotype. A specimen from the Cody Shale of the Wind River Basin in Wyoming (fig. 1, loc. 24) shows the suture very well (pl. 2, fig. 28). The suture is typical of Haresiceras and almost as complex as that of $H$. placentiforme and $H$. natronense. The only noticeable difference is in the second lateral saddle which is symmetrically bifid in contrast to the asym- metry of this saddle in $H$. placentiforme and $H$. natronense.

Occurrence: The holotype is from $150 \mathrm{ft}$ below the Elk Basin Sandstone Member of the Telegraph Creek Formation in Carbon County, Mont. (fig. 1, loc. 9; not from Elk Basin Sandstone Member as stated on explanation of pl. 22 in Prof. Paper 151). The only other localities for the older form of H. montanaense are on Porcupine dome in east-central Montana (fig. 1, locs. 6, 7). The younger form is more widespread and is known from the basal part of the Telegraph Creek Formation and just below it in the northern part of the Bighorn Basin in Wyoming (fig. 1, locs. 16, 17), from the upper part of the Cody Shale of the Wind River Basin in Wyoming (fig. 1, locs. 24, 28,29 ), from the Cody Shale on the east side of the Bighorn Mountains of Wyoming (fig. 1, loc. 19), from the lower part of the Steele Shale near Rawlins, Wyo. (fig. 1, loc. 32), and from the upper part of the Mancos Shale in northeastern Utah (fig. 1, locs. 36, 37).

Types: Holotype USNM 73364; plesiotypes USNM 131466131482 .

Subgenus Mancosiceras Cobban, n. subgen.

Type species.-Haresiceras (Mancosiceras) mancosense (Reeside).

The distinguishing characters are the well-ribbed compressed whorls, the tendency of the septate whorls to be round ventered, and the confinement of the nodose ventrolateral edge to the body chamber.

Haresiceras (Mancosiceras) mancosense (Reeside)

Plate 1, figures 14-27; plate 2, figures 41-48

1927. Puzosia (Latidorsella) mancosensis Reeside, U.S. Geol. Survey Prof. Paper 151, p. 15, pl. 12, figs. 1-8.

1960. Desmophyllites mancosensis (Reeside). Fisher, Erdmann, and Reeside, U.S. Geol. Survey Prof. Paper 332, p. 29.

Reeside based this species on five juveniles from three localities. The holotype is a septate coil $24 \mathrm{~mm}$ in diameter. It is moderately stout and has flattened flanks, rounded venter, and a very small umbilicus. The complete whorl has six or seven weak constrictions that extend from the umbilicus across the flank and over the venter. Strong forwardly arched ribs cross the venter but weaken and disappear at about the middle of the flank. Ribs are not visible on the older part of the whorl but 21 are present on the younger half of the whorl.

The suture of the holotype (pl. 1, fig. 21) is typical of the genus in its trifid lateral lobes, narrow second lateral saddle, and broad third lateral saddle. The second lateral saddle is symmetrically bifid like that of H. montanaense.

The writer assigns two forms to this species, one characterized by a rounded venter on most or all of the septate whorls and the other marked by a flattening of the venter early on the last septate whorl. The roundventered form, which includes the holotype, is interpreted as the older. 
The best collection at hand of the round-ventered form consists of four uncrushed specimens, all septate coils $25-38 \mathrm{~mm}$ in diameter, from a bed of limestone concretions near the base of the Gammon Shale near Mosby in east-central Montana (fig. 1, loc. 5). The presence of a septate individual (pl. 1, figs. 16-18) $38 \mathrm{~mm}$ in diameter suggests that the larger adults attained a size comparable to that of adult $H$. natronense (pl. 3, fig. 17). This septate specimen has the venter flattened at an earlier growth stage than that of the associated specimens. One fragment (pl. 1, figs. $14,15)$ has closely spaced ventral ribs of even height, but on the flank they are differentiated into flexuous primary and secondary ribs, the primaries extending to the umbilicus. This fragment is probably from the younger end of the septate coil of an adult.

The septate whorls of a specimen (pl. 1, figs. 25, 26) from the Sweetgrass arch in northwestern Montana (fig. 1, loc. 1) have weaker ribbing than that of any of the specimens from the Mosby locality. This individual, $21 \mathrm{~mm}$ in diameter, has seven conspicuous constrictions on the complete whorl and 27 ventral ribs on the last half whorl of which all are very weak except those on the oral side of the constrictions. Reeside (1927a, p. 16) considered this specimen as a new species.

The body chamber of the early form of $H$. (M.) mancosense is represented by a single fragment from the upper part of the Cody Shale in the Wind River Basin of Wyoming (fig. 1, loc. 23). This fragment (pl. 1, fig. 27) reveals a slightly arched venter, welldefined ventrolateral shoulder, and flattened flanks. The venter has ribs of even height and spacing that bend forward slightly. For every four ribs a sharp node rises from the ventrolateral shoulder. Sculpture on the flanks is obscured by weathering.

The flat-ventered or younger form of the species is known with certainty only from the Telegraph Creek Formation along the Marias River near Shelby Mont. The largest collection consists of four septate coils 24-26 $\mathrm{mm}$ in diameter and part of a body chamber from a sandstone unit in the lower part of the Telegraph Creek Formation (fig. 1, loc. 2). The best specimen (pl. 2, figs. 41, 42), $26 \mathrm{~mm}$ in diameter, has the venter rounded on the earliest part visible (diam of about $14 \mathrm{~mm}$ ) but distinctly flattened on the last half of the whorl where the ventrolateral shoulder is sharply rounded. Forwardly arched strong ribs cross the venter; these number 32 or 33 for the complete whorl. The flanks of most of the early half of the whorl are smooth but, beginning at a diameter of $19 \mathrm{~mm}$, the ventral ribs pass into sinuous primaries that extend to the umbilicus and secondaries that weaken and disappear on the outer third of the flank. The primaries bend back slightly on leaving the umbilicus then curve forward to a point about two-thirds of the distance to the edge of the venter where they gently turn back a little and then arch slightly forward to the ventral margin. Only parts of the suture are visible, but these reveal a pattern about as complex as that of the holotype of $H$. (M.) mancosense.

Fragments of three body chambers (pl. 2, figs. 43-48) from the Telegraph Creek Formation in the Shelby area (fig. 1, locs. 2-4) are interpreted as belonging to the flat-ventered form of this species. These have broad gently arched venters, flattened flanks, and a welldefined angular ventrolateral margin. The venter is crossed by numerous ribs that bend forward a little. Ribbing on the flank is likewise dense but is differentiated into primaries and secondaries. Each primary ends in a small pointed node on the ventrolateral shoulder. Two or three secondaries are present for each primary. The largest specimen (pl. 2, figs. 47, 48 ) is more coarsely ribbed than the others and probably is as large as H.natronense (pl. 3, fig. 17).

Reeside (1927a, p. 15) originally assigned his species to Puzosia (Latidorsella). Latidorsella Jacob (1907, p. 35 ) is an objective synonym of Desmoceras Zittel (1884, p. 465) which differs from Reeside's species by its stouter form, wider umbilicus, and suture that has more numerous lobes and saddles, all of which decrease regularly in size away from the venter. Later Reeside (in Fisher and others, 1960, p. 29) assigned his species to Desmophyllites Spath (1929, p. 270) of Santonian and Campanian age. Desmophyllites is a much larger ammonite that has a deeply digitate desmoceratid suture.

Occurence: The holotype is from $160 \mathrm{ft}$ below the top of the Mancos Shale in San Jaun County, N. Mex. (fig. 1, loc. 43). The paratypes came from the Telegraph Creek Formation in southcentral Montana (fig. 1, locs. 8, 10). Other specimens came from the Telegraph Creek and the uppermost part of the Marias River Shale in northwestern Montana (fig. 1, locs. 1-4), from the Cody Shale in the Wind River Basin of west-central Wyoming (fig. 1, loc. 23), from the Baxter Shale near Rock Springs, Wyo. (fig. 1, loc. 31), and from the Mancos Shale of east-central Utah (fig. 1, loc. 38 ).

Types: Holotype USNM 73314; paratypes USNM 73313, 73314 ; plesiotypes USNM 131455-131463.

\section{LITERATURE CITED}

Basse, F́laine, 1952, Classe des Céphalopodes, in Jean Piveteau, Traité de Paléontologie, pt. 2, p. 461-688, pls. 1-24.

Cobban, W. A., 1950, Telegraph Creek Formation of Sweetgrass arch, north-central Montana: Am. Assoc. Petroleum Geologists Bull., v. 34, no. 9, p. 1899, 1900.

1951a, Colorado shale of central and northwestern Montana and equivalent rocks of Black Hills: Am. Assoc. Petroleum Geologists Bull., v. 35, no. 10, p. 2170-2198, 2 figs. 
Cobban, W. A., 1951b, Scaphitoid cephalopods of the Colorado group: U.S. Geol. Survey Prof. Paper 239, 42 p., 21 pls., 4 text figs. [1952].

1953, An Upper Cretaceous section near Mosby, Montana, in Billings Geol. Soc. Guidebook 4th Ann. Field Conf., Little Rocky Mountains, Montana-Southwestern Saskatchewan, 1953 : p. $98-101$.

1955, Cretaceous rocks of northwestern Montana, in Billings Geol. Soc. Guidebook 6th Ann. Field Conf., Sweetgrass arch-Disturbed belt, Montana, 1955: p. 107-119, 9 figs.

1962, Late Cretaceous Desmoscaphites Range Zone in the western interior region, in Short papers in geology hydrology, and topography: U.S. Geol. Survey Prof. Paper 450-D, p. D140-D144.

Cobban, W. A., and Reeside, J. B. Jr., 1952, Correlation of the Cretaceous formations of the Western Interior of the United States: Geol. Soc. America Bull., v. 63, no. 10, p. 1011-1043.

Cobban, W. A., Scott, G. R., and Gill, J. R., 1962, Recent discoveries of the Cretaceous ammonite Haresiceras and their stratigraphic significance, in Short papers in geology, hydrology, and topography : U.S. Geol. Survey Prof. Paper 450-B, p. B58-B60.

Collier, A. J., 1929, The Kevin-Sunburst oil field and other possibilities of oil and gas in the Sweetgrass arch, Montana : U.S. Geol. Survey Bull. 812-B, p. 57-189, pls. 11-18 [1930].

Dobbin, C. E., and Erdmann, C. E., 1955, Structure contour map of the Montana Plains: U.S. Geol. Survey Oil and Gas. Inv. Map OM-178-B.

Dobbin, C. E., Kramer, W. B., Miller, J. C., and French, H. F., 1944, Geologic and structure map of the Elk Basin oil and gas field and vicinity, Park County, Wyoming, and Carbon County, Montana : U.S. Geol. Survey.

Fisher, D. J., Erdmann, C. E., and Reeside, J. B., Jr., 1960, Cretaceous and Tertiary formations of the Book Cliffs, Carbon, Emery, and Grand Counties, Utah, and Garfield and Mesa Counties, Colorado: U.S. Geol. Survey Prof. Paper 332, 80 p., 12 pís., 1 fig.

Grossouvre, A. de, 1893, Récherches sur la craie supérieure; pt. 2, Paléontologie. Les Ammonites de la craie supérieure : Carte Géol. France Mém., 264 p., pls. 1-39.

Hose, R. K., 1955, Geology of the Crazy Woman Creek area, Johnson County, Wyoming: U.S. Geol. Survey Bull. 1027-B, p. 33-118, pls. 6-13, figs. 13-27, [1956].

Jacob, Charles, 1907, Étude sur quelques Ammonites du Crétacé moyen: Soc. géol. France, Mém., Paléont., v. 15, no. 38, p. 1-64, 9 pls. [1908].
Keefer, W. R., and Troyer, M. L., 1956, Stratigraphy of the Upper Cretaceous and lower Tertiary rocks of the Shotgun Butte area, Fremont County, Wyoming: U.S. Geol. Survey Oil and Gas Inv. Chart OC-56.

Reeside, J. B., Jr., 1924, Upper Cretaceous and Tertiary formations of the western part of the San Juan Basin, Colorado and New Mexico: U.S. Geol. Survey Prof. Paper 134, p. 1-70, pls. 1-4, text figs. 1-5.

1927a, The cephalopods of the Eagle sandstone and related formations in the Western Interior of the United States: U.S. Geol. Survey Prof. Paper 151, 87 p., 45 pls. 1927b, The scaphites, an Upper Cretaceous ammonite group: U.S. Geol. Survey Prof. Paper 150-B, p. 21-40, pls. 9-11.

1944, Maps showing thickness and general character of the Cretaceous deposits in the western interior of the United States: U.S. Geol. Survey Oil and Gas Prelim. Map 10.

Reeside, J. B., Jr., and Cobban, W. A., 1960, Studies of the Mowry shale (Cretaceous) and contemporary formations in the United States and Canada: U.S. Geol. Survey Prof. Paper 355, 126 p., 58 pls., 30 text figs.

Richards, P. W., 1955, Geology of the Bighorn Canyon-Hardin area, Montana and Wyoming: U.S. Geol. Survey Bull. 1026, 93 p., 7 pls., 8 text figs [1956].

Seitz, Otto, 1956, Über Ontogenie, Variabilität und Biostratigraphie einiger Inoceramen: Palaeont. Zeitschr., v. 30, p. 3-6.

Spath, L. F., 1929, Corrections of cephalopod nomenclature: The Naturalist, no. 871, p. 269-271.

Thom, W. T., Jr., Hall, G. M., Wegemann, C. H., and Moulton, G. F., 1935, Geology of Big Horn County and the Crow Indian Reservation, Montana, with special reference to the water, coal, oil, and gas resources: U.S. Geol. Survey Bull. 856, 200 p., 15 pls., 13 text figs.

Wegemann, C. H., 1918, The Salt Creek oil field, Wyoming: U.S. Geol. Survey Bull. 670, 52 p., 7 pls.

Wilson, J. B., 1951, Stratigraphy of the Sussex Sandstone, Powder River Basin, Wyoming: Wyoming Geol. Survey Rept. Inv. 3, p. 1-11, pls. 1-3.

Wright, C. W., 1957, Hoplitaceae, in Arkell, W. J., Kummel, Bernard, and Wright, C. W., Mesozoic Ammonoidea: Treatise on invertebrate paleontology, R. C., Moore, ed., Part L, Mollusca 4, p. L80-L465.

Yenne, K. A., and Pipiringos, G. N., 1954, Stratigraphic sections of Cody shale and younger Cretaceous and Paleocene rocks in the Wind River Basin, Fremont County, Wyoming: U.S. Geol. Survey Oil and Gas Inv. Chart OC-49.

Zittel, K. A. von, 1884, Handbuch der Palaeontologie, v. 2, p. 1-893, figs. 1-1109. 



\section{INDEX}

[Italic numbers indicate descriptions]

Page

Acanthoceras montanaense.............. I 1, 4, 5, 6, 16 alcesense, Eutrephoceras....................... 8 aquilaensis, Baculites.................. 6, 8, 10,11 costatus, Scaphites......................... 8 nanus, Scaphites Scaphites ........... 6, aquisgranensis, Scaphites.............. 6, 8, 9, 10,11 asper, Baculites.

Baculites aquilaensis.................. 6,8,9,10,11 asper................................... $\quad 9$ haresi............................. 5, $6,10,11$ minerensis obtusus . thomi_.............................. 5, 6,11 sp bassleri, Desmoscaphites......... _ . 1,4, 5,8,9,10,11

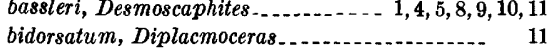
binodosus, Scaphites

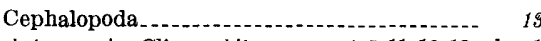
choteauensis, Clioscaphites_...... 4, 5, 11,12,13, pl. 1 Clioscaphites choteauensis................... 4, $5,11,12,13, \mathrm{pl} .1$ platygastrus. ..................... 1, 12,13, pl. 3 vermiformis.......... 4, $5,6,8,9,10,11,12,13, \mathrm{pl} .1$ toolensis............................... 12, 13 cordiformis, Inoceramus. . . . _............... 4, 4 costatus, Scaphites aquilaensis .................. 8 crassus, Scaphites hippocrepis................ $\quad 8,9$

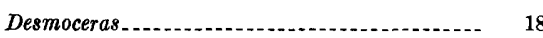
Desmophyllites.................................. 18 mancosensis

Desmoscaphites........................ 1, $11,12,13$ bassleri....................... 1, $4,5,8,9,10,11$ erdmanni.................... 4,5,6,11,12, pl. 1 sp. Diplacmoceras bidorsatum........ 11

erdmanni, Desmoscaphites.......... 4, 5,6,11, 12, pl. 1 Eutrephoceras alcesense.

fisheri, Haresiceras $1,10,11,16, \mathrm{pl}, 3$ Forbesiceras. 11

Glyptoxoceras rubeyi. $8,9,10$

Gonioteuthis granulato 11 quadrata. oranulata, Gonioteuthis haresi, Baculites.

Page

Haresiceras.

$5,6,9,10,11$ $1,5,6,9,11,12,18$ fisheri_...................... 1,10,11, 16, pl. 3 mancosense............................. 1,5,11 montanaense ...... $1,8,9,10,11,12,13,16,17, \mathrm{pl} .2$ natronense .... $1,6,7,9,10,11,13,15,16,17,18, \mathrm{pl} .3$ placentiforme....... 1, 6, 8, 9, 10,11, 13, 16,17, pl. 3 parvum.

(Mancosiceras) mancosense $5,6,8,9,10,11,12,17,18$, pls. 1,2 Hauericeras pseudogardeni.-.............. 11 hippocrepis, Scaphites_.. 1,4,5,6,7,8,9,10,11,16, pl. 1 crassus, Scaphites.................... 8,9 pusillus, Scaphites............ 8 tenuis, Scaphites $\ldots \ldots \ldots \ldots \ldots \ldots$

Hoplites...................................... 11,12

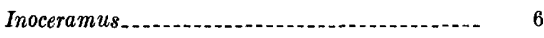
cordiformis_.............................. 4,11

lundbreckensis. . . ......................... 5,9 patootensis........................ 5,6,8,9,10,11

Latidorsella

(Latidorsella), Puzosia....................... 18 mancosensis, Puzosia leei, Scaphites_.................. 5, 8, 9, 10,11, 16, pl. 1 levis, Scaphites.................................. 8 lundbreckensis, Inoceramus_._........... $\quad 5,9$

mancosense, Haresiceras....................... 1,5,11 Haresiceras (Mancosiceras) -...........-... 1 , $5,6,8,9,10,11,12,17,18$, pls. 1,2

mancosensis, Desmophyllites ................ 17

Puzosia (Latidorsella)

Mancosiceras .................................. 5,17

(Mancosiceras) mancosense, Haresiceras....... 1, $5,6,9,10,11,12,17,18$, pls. 1,2 Marsupites

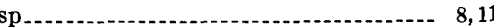
Metaplacenticeras............................. 11 minerensis, Baculites........................ 9 montanaense, Acanthoceras ................. 1, 4,5,16 Haresiceras........- 1, 8, 9, 10,11, 12,13,16,17, pl. 2

nanus, Scaphites aquilaensis.................... 8 natronense, Haresiceras ......................... 1 $6,7,9,10,11,13,15,16,17,18, \mathrm{pl} .3$

obtusus, Baculites

$6,7,8,9,10$
Page

parvum Haresiceras placentiforme. patootensis, Inoceramus Placenticeras.................................. 11

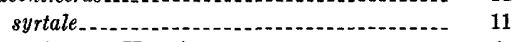
placentiforme, Haresiceras..................... 1 , $6,8,9,10,11,13,16,17$, pl. 3 parvum, Haresiceras....................... 6 platygastrus, Clioscaphites............... 1,12, 13, pl. 3 pseudogardeni, Hauericeras..................... 11 pusillus, Scaphites hippocrepis Puzosia mancosensis..................... 9 (Lntidorsella) ........................... 18 mancosensis_........................ 1,4,5,17 (Schlueteria)

quadrata, Gonioteuthis_._. 11

rubeyi, Glyptoxoceras

Scaphites ..... 6, 7,13

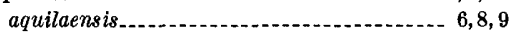
costatus_.......... 8 nanus aquisgranensis. . . .................. $6,8,9,10,11$ binodosus. hippocrepis......... 1, 4, 5,6,7,8,9,10,11,16, pl. 1 crassus . . . pusillus_................................ 8 tenuis .................................. 6,9

leei-_. 5, 6,8,9,10,11,16, pl. 1

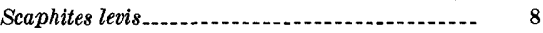

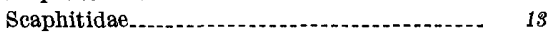
(Schlueteria), Puzosia......................... 5 socialis, Uintacrinus...................... 5,11

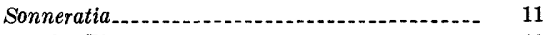
syrtale, Placenticeras......................... 11

tenuis, Scaphites hippocrepis................. 6,8,9

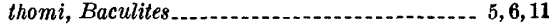

toolensis, Clioscaphites vermiformis.............. 12,13

Uintacrinus._...
socialis_. sp

vermiformis, Clioscaphites.....-.........-. 4 , $5,6,8,9,10,11,12,13, \mathrm{pl} .1$
toolensis, Clioscaphites $1 . . . . . . . . . .12,13$ 

PLATES 1-3 


\section{PLATE 1}

[All figures natural size except as indicated on plate]

FiguRes 1-7. Desmoscaphites erdmanni Cobban (p. I 12).

From $10 \mathrm{ft}$ below top of Marias River Shale at USGS Mesozoic loc. 21419, 8 miles west of Shelby, Toole County, Mont.

1, 2, 7. Side and rear views of an internal mold of a young specimen showing constrictions, forwardly arched ventral ribs, and last suture $(\times 3)$. USNM 106725a.

3,4 . Side and front views of a smaller specimen showing constrictions and lack of ribbing on the early whorls. USNM 106725d.

5, 6. Front and side views of an incomplete specimen showing the coarse-ribbed outer septate whorl and beginning of the fine-ribbed body chamber. USNM 106725c.

8-10. Clioscaphites choteauensis Cobban (p. I 12).

Side, rear, and front views of a juvenile from upper part of Marias River Shale at USGS Mesozoic loc. 23889, in the E $1 / 2$ sec. 31 , T. 32 N., R. 3 W., Toole County, Mont. Note the forwardly arched ventral ribbing, lack of constrictions, and stouter shell than that of fig. 2. USNM 131454.

11-13. Clioscaphites vermiformis (Meek and Hayden) (p. I 12).

Side, rear, and front views of a septate coil from limestone concretions 234-252 ft below top of Marias River Shale at USGS Mesozoic loc. 21425, 11 miles southwest of Shelby, Toole County, Mont. This individual has forwardly arched ventral ribbing similar to that of figs. 2 and 9 but differs readily by its stouter shell. USNM $106713 \mathrm{e}$.

14-27. Haresiceras (Mancosiceras) mancosense (Reeside) (p. I 17).

14, 15. Rear and side views of a fragment showing slightly flexuous primary and secondary ribbing near the end of the septate coil. From a limestone concretion collected at loc. 5 (fig. 1). USNM 131455.

16-18. Side, front, and rear views of a very large septate coil from the same locality as fig. 14. USNM 131456.

19-21. Side and rear views and suture $(X 4)$, of the holotype collected from $160 \mathrm{ft}$ below top of Mancos Shale at loc. 43 (fig. 1), San Juan County, N. Mex. USNM 73314. After Reeside.

22-24. Side, rear, and front views of a septate coil from the same locality as fig. 14 . This individual lacks constrictions, but it does show the compressed whorl section, strong forwardly arched ventral ribbing, and flexuous flank ribbing. USNM 131457.

25, 26. Side and rear views of a septate internal mold collected from loc. 1 (fig. 1). This specimen has welldefined constrictions but unusually weak ribs. USNM 131458.

27. View of part of the venter of an adult showing three of the ventrolateral nodes; collected from loc. 23 (fig. 1). USNM 131459.

28-30. Scaphites cf. S. hippocrepis (DeKay) (p. I 8).

Side, top, and rear views of an adult, an internal mold, from upper part of Elk Basin Sandstone Member of Telegraph Creek Formation at USGS Mesozoic loc. D3295, in the SE1/4 sec. 19, T. 58 N., R. 99 W., Park County, Wyo. This specimen, transitional to $S$. leei Reeside, has the coarse ribbing that characterizes the scaphites from the lower and middle parts of the S. hippocrepis Range Zone. USNM 131464.

31, 32. Scaphites leei Reeside (p. I 11).

Rear and side views of the holotype from upper part of Mancos Shale at USGS Mesozoic loc. 7165, 1 mile southwest of Waldo, Santa Fe County, N. Mex. USNM 73354. After Reeside.

33-36. Scaphites hippocrepis (DeKay) (p. I 8).

Side, top, rear, and front views of an adult retaining much of the shell, from Cody Shale at USGS Mesozoic loc. 21206, 6 miles east of Hardin, Big Horn County, Mont. This specimen has the fine ribbing characteristic of the scaphites in the upper part of the S. hippocrepis Range Zone. USNM 131465. 

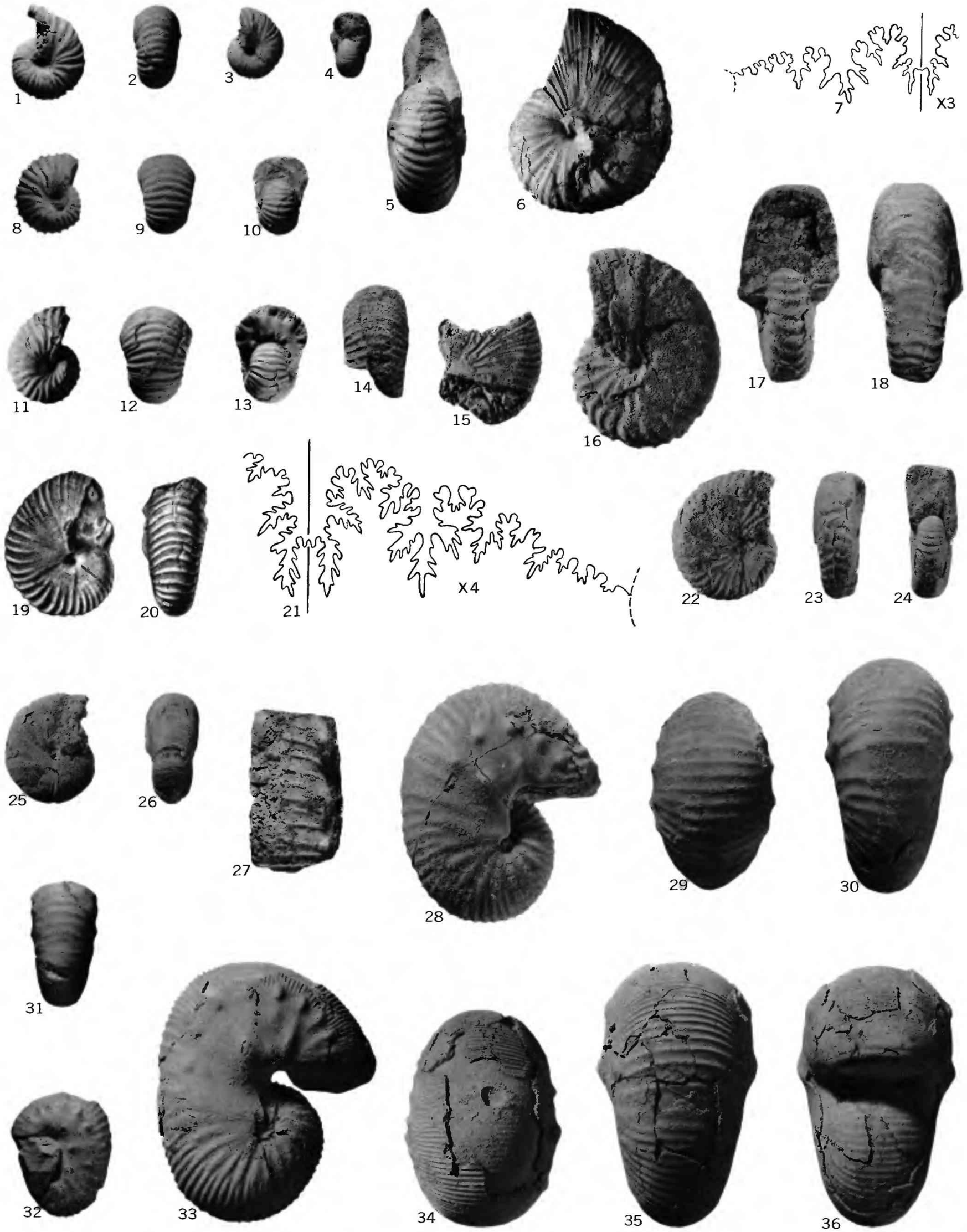

DESMOSCAPHITES, CLIOSCAPHITES, HARESICERAS, AND SCAPHITES 


\section{PLATE 2}

[All figures natural size except as indicated on plate]

FigURES 1-40. Haresiceras montanaense (Reeside) (p. I 16).

1, 2. Side and rear views of a small juvenile representing the early form of the species; collected from loc. 7 (fig. 1). USNM 131472.

3. Rear view of a slightly larger and more slender individual from the same locality showing a constriction. USNM 131473.

4. Rear view of a large juvenile from the same locality showing constrictions bordered by strong ribs. USNM 131474.

5, 6. Side and rear views of a juvenile collected from loc. 19 (fig. 1). This specimen represents the younger and more slender form of the species. USNM 131468.

7-9. Side, rear, and front views of a young septate specimen, an internal mold collected from loc. 6 (fig. 1). This individual is very slender for the early form of the species. USNM 131466.

10-12. Side, rear, and front views of another internal mold collected from loc. 6 (fig. 1). This specimen is of average stoutness for the early form and shows a constriction. USNM 131467.

13-24. Side and rear views of six juvenile specimens collected from loc. 7 (fig. 1) showing variation in stoutness and in the appearance of a flattened venter and ribbing. USNM 131475-131480.

25-28. Side, rear, and front views and suture $(\times 4)$, of a septate representative of the younger or slender form of the species; collected from loc. 24 (fig. 1). USNM 131471.

29,30 . Side and rear views of a very small adult collected from loc. 17 (fig. 1) showing well-ribbed flanks and, near the aperture, very small ventrolateral nodes. USNM 131481.

31-34. Two side, rear, and front views of the holotype collected from loc. 9 (fig. 1). USNM 73364. After Reeside.

35,36 . Side and rear views of a septate specimen representing the younger form of the species, from the same locality as fig. 5. USNM 131469.

37, 38. Side and rear views of most of a large adult body chamber collected from loc. 16 (fig. 1). USNM 131482.

39,40 . Side and rear views of a small adult of the younger form of the species from the same locality as fig. 5 . USNM 131470.

41-48. Haresiceras (Mancosiceras) mancosense (Reeside) (p. I 17).

41, 42. Side and rear views of a septate specimen representing the late form of the species; collected from loc. 2 (fig. 1). USNM 131460.

43, 44. Side and rear views of part of a body chamber from the same locality as fig. 41. USNM 131461.

45, 46. Rear and side views of part of a body chamber of the late form; collected from loc. 3 (fig. 1) and showing primary and secondary ribs and small ventrolateral nodes. USNM 131462.

47, 48. Side and rear views of part of a large coarse-ribbed body chamber of an adult of the late form of the species; collected from loc. 4 (fig. 1). USNM 131463. 
GEOLOGICAL SURVEY

PROFESSIONAL PAPER 454-I PLATE 2

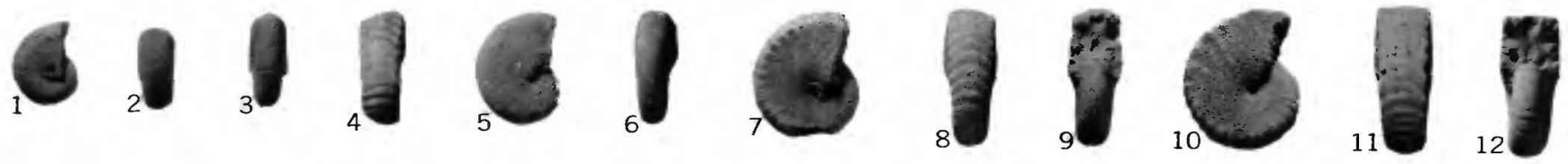
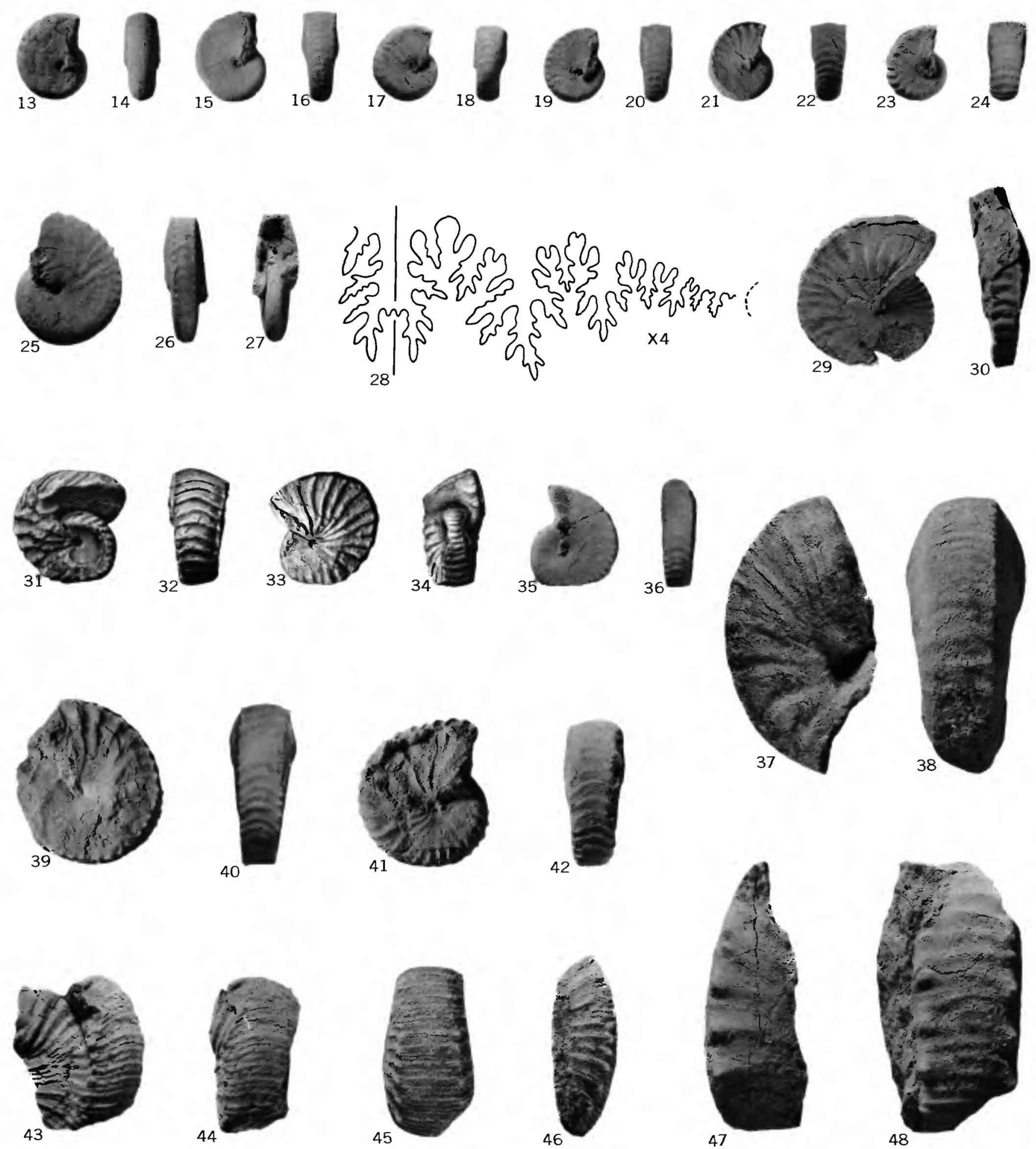

HARESICERAS 


\section{PLATE 3}

[All figures natural size except as noted on plate]

Figures 1-6. Haresiceras placentiforme Reeside (p. I 13).

1-4. Side, front, and rear views and suture $(\times 4)$, of the septate whorls of a specimen collected from loc. 13 (fig. 1). USNM 131483.

5, 6. Side and rear views of part of a juvenile from the same locality. USNM 131484 .

7-9. Haresiceras fisheri Reeside (p. I 16).

Side, rear, and front views of the holotype; collected from loc. 39 (fig. 1). USNM $73387 . \quad$ After Reeside.

10-13. Clioscaphites platygastrus Cobban (p. I 12).

Part of suture $(\times 3)$, and side, bottom, and top views of the holotype from near top of Marias River Shale 4 miles west of Sunburst, Toole County, Mont. USNM 106729.

14-21. Haresiceras natronense Reeside (p. I 15).

From marlstone concretions in lower part of Gammon Ferruginous Member of Pierre Shale; collected at loc. 35 (fig. 1).

14-16. Side, rear, and front views of a septate coil. USNM 131485.

17-19, 21. Suture $(\times 4)$, two side views of a partly crushed adult, and a front view of the last septate whorl with part of the crushed body chamber. USNM 131486.

20. View of part of an adult showing the shape of the aperture. USNM 131487. 

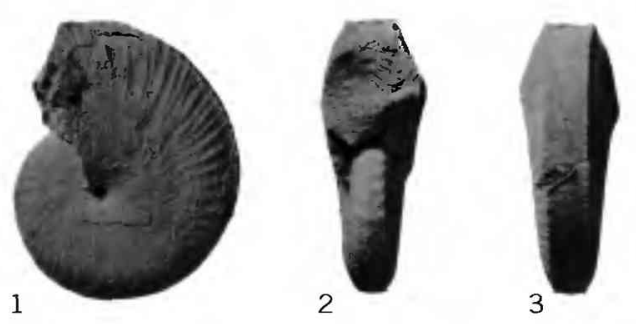

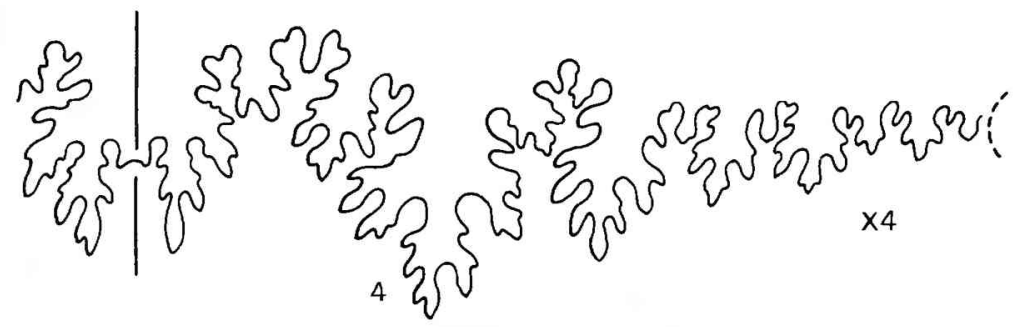
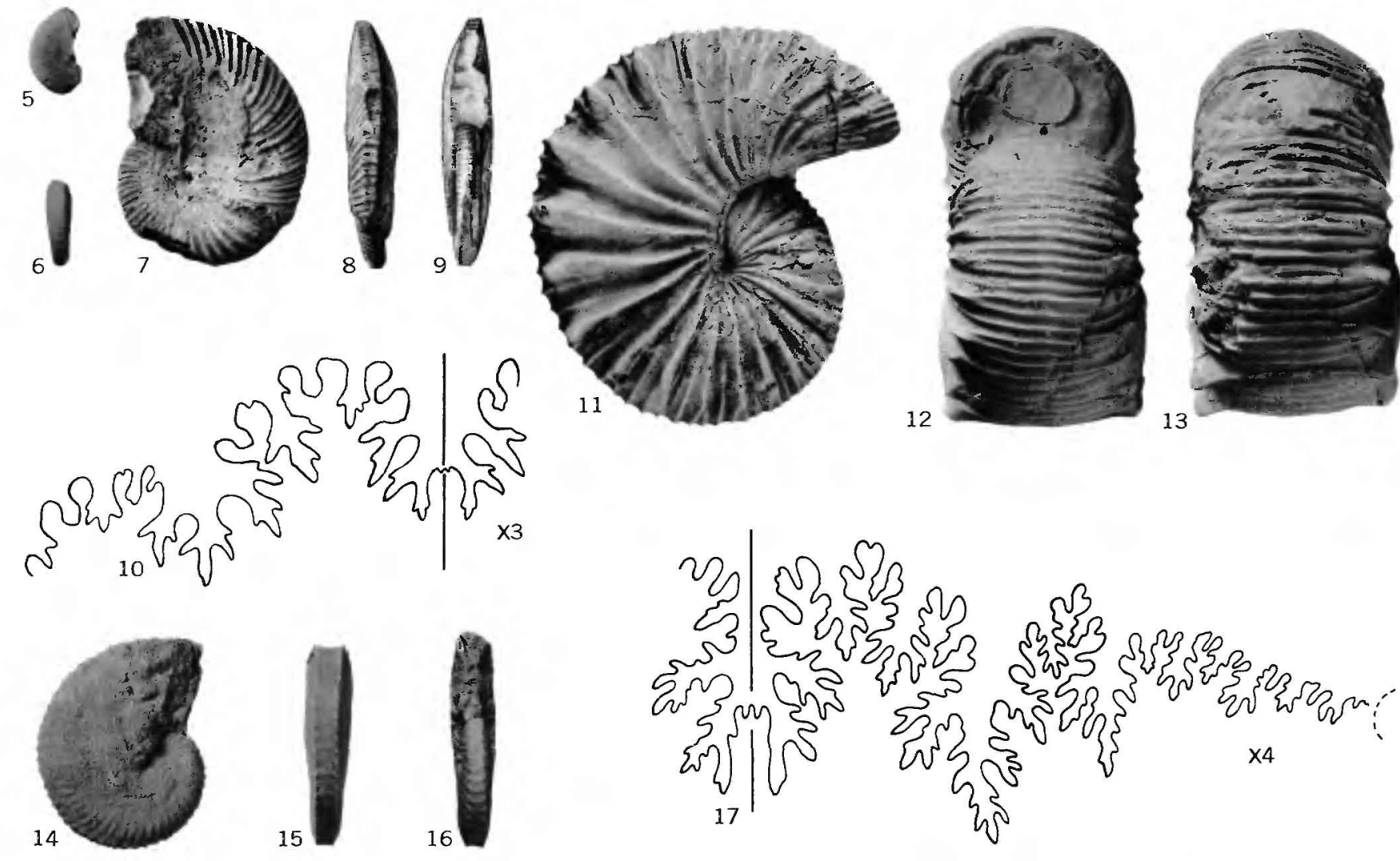

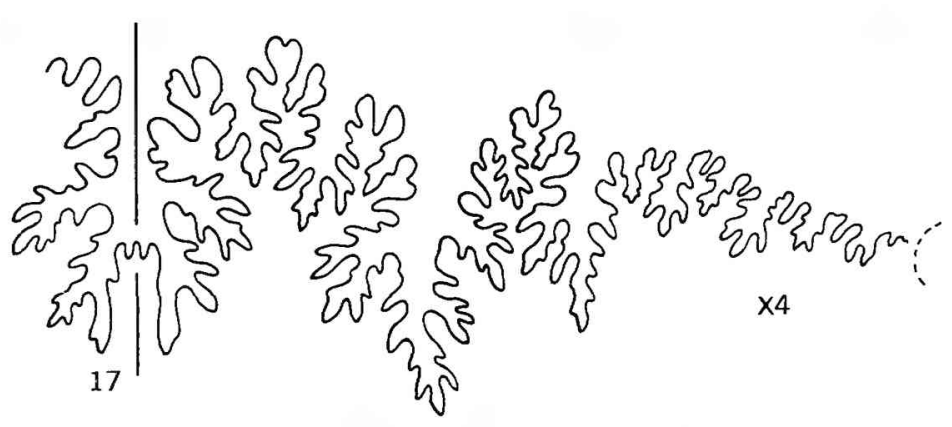
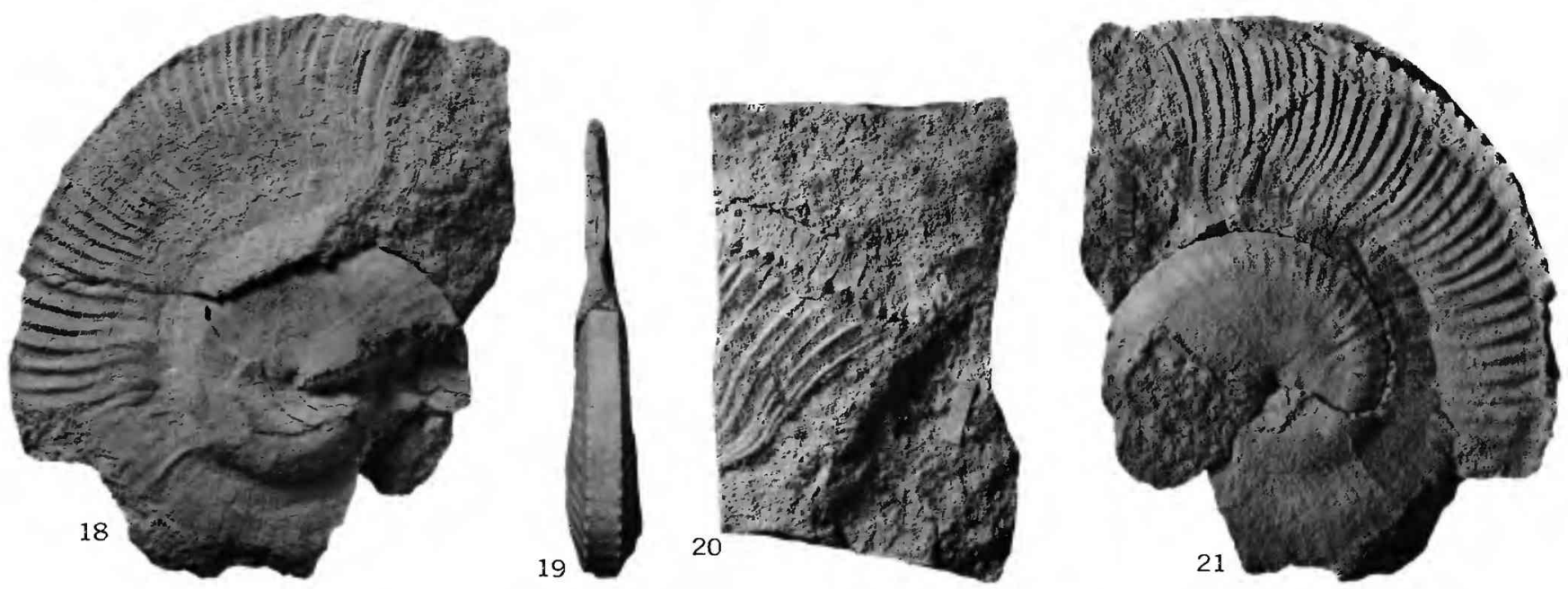